\title{
Targeting Adenosine Receptor Signaling in Cancer Immunotherapy
}

\author{
Kevin Sek ${ }^{1,2}$, Christina Mølck ${ }^{3}$, Gregory D. Stewart ${ }^{4}\left(\mathbb{D}\right.$, Lev Kats ${ }^{1,2}$, Phillip K. Darcy ${ }^{1,2,3,5, *, \uparrow}$ \\ and Paul A. Beavis $1,2, *,+$ \\ 1 Cancer Immunology Program, Peter MacCallum Cancer Centre, East Melbourne, Victoria 3000, Australia; \\ Kevin.Sek@petermac.org (K.S.); lev.kats@petermac.org (L.K.) \\ 2 Sir Peter MacCallum Department of Oncology, The University of Melbourne, 3010 Parkville, Australia \\ 3 Department of Pathology, University of Melbourne, Parkville 3010, Australia; christina.moelck@gmail.com \\ 4 Drug Discovery Biology, Monash Institute of Pharmaceutical Sciences and Department of Pharmacology, \\ Monash University, Parkville 3052, Australia; gregory.stewart@monash.edu \\ 5 Department of Immunology, Monash University, Clayton 3052, Australia \\ * Correspondence: phil.darcy@petermac.org (P.K.D.); Paul.Beavis@petermac.org (P.A.B.); \\ Tel.: +613-8559-7093 (P.K.D.); +613-8559-5051 (P.A.B.) \\ + These authors contributed equally to this work.
}

Received: 30 October 2018; Accepted: 27 November 2018; Published: 2 December 2018

check for updates

\begin{abstract}
The immune system plays a major role in the surveillance and control of malignant cells, with the presence of tumor infiltrating lymphocytes (TILs) correlating with better patient prognosis in multiple tumor types. The development of 'checkpoint blockade' and adoptive cellular therapy has revolutionized the landscape of cancer treatment and highlights the potential of utilizing the patient's own immune system to eradicate cancer. One mechanism of tumor-mediated immunosuppression that has gained attention as a potential therapeutic target is the purinergic signaling axis, whereby the production of the purine nucleoside adenosine in the tumor microenvironment can potently suppress $\mathrm{T}$ and NK cell function. The production of extracellular adenosine is mediated by the cell surface ectoenzymes CD73, CD39, and CD38 and therapeutic agents have been developed to target these as well as the downstream adenosine receptors $\left(A_{1} R, A_{2 A} R, A_{2 B} R, A_{3} R\right)$ to enhance anti-tumor immune responses. This review will discuss the role of adenosine and adenosine receptor signaling in tumor and immune cells with a focus on their cell-specific function and their potential as targets in cancer immunotherapy.
\end{abstract}

Keywords: Adenosine; Adenosine receptors; immune cells; tumor cells; cancer immunotherapy

\section{Introduction}

Adenosine triphosphate (ATP) is a ubiquitous molecule that plays a vital role as the universal energy currency within the cell. Under physiological conditions, intracellular ATP concentrations are maintained at millimolar concentrations, while extracellular levels are tightly regulated in the nanomolar range [1,2]. However, under certain conditions, such as tissue injury, inflammation, ischemia, or in the tumor microenvironment (TME), extracellular ATP levels increase due to release from inflammatory, apoptotic, or necrotic cells [3]. Extracellular ATP signals through P2 receptors (P2R) that are widely expressed on immune and non-immune cells within the body and are involved in multiple physiological and pathological processes. The current paradigm of purinergic signaling on the immune response can be described as a balance between pro- and anti-inflammatory signaling from extracellular ATP and adenosine (ADO), respectively. Physiologically, ATP released from stressed, apoptotic, and necrotic cells can act as a 'danger signal' during the acute inflammatory response 
and is essential for the clearance of intracellular bacteria, parasites, and viruses [4]. ATP can also induce a form of immunogenic cell death in cancer cells that promotes immunosurveillance in the TME (reviewed in [5]). In contrast, ADO is mainly anti-inflammatory and promotes cytoprotection [6], wound healing [7], and suppression of the immune system. Whilst the concentration of ADO in normal tissue resides around nanomolar concentrations, it has been shown to be present at up to micromolar concentrations in solid tumors and enriched in the hypoxic tumor core $[2,8,9]$. Increased $\mathrm{ADO}$ levels are furthermore observed in inflammation, ischemia, hypoxia, and organ trauma, and is a major component in the regulation of immune cells in the context of bacterial/viral sepsis or renal dysfunction or injury (reviewed in $[10,11]$ ). The critical role for ADO signaling in immune regulation is further emphasized by the total dysfunction of T cells, NK cells, and B cells in individuals with a variant of severe combined immunodeficiency (SCID) as a result of mutations in adenosine deaminase (ADA) that catalyzes the conversion of ADO to inosine [12].

There are four known subtypes of $A D O$ receptors $\left(A_{1} R, A_{2 A} R, A_{2 B} R, A_{3} R\right)$ which have distinct expression patterns and mediate diverse signaling pathways. Due to the presence of high concentrations of ADO within the TME and the expression of ADO receptors on tumor and immune cells, the role of ADO in cancer progression and anti-tumor immune responses have been intensively investigated. This has led to the clinical development of antibodies and small molecule inhibitors targeting various components of the $\mathrm{ADO}$ pathway including CD39, CD38, CD73, $\mathrm{A}_{2 \mathrm{~A}} \mathrm{R}$, and $\mathrm{A}_{2 \mathrm{~B}} \mathrm{R}$. Despite this, the mechanisms of action of these reagents in terms of their target cell population and intracellular signaling pathways remain relatively unknown. This review will discuss the signaling pathways in which ADO receptors mediate their effect in both tumor and immune cells, and recent progress in targeting the ADO pathway to improve immunotherapies.

\section{Extracellular Adenosine Production in the Tumor Microenvironment}

The TME exhibits high concentrations of ADO due to the contribution of immune and stromal cells, tissue disruption, and inflammation. A predominant driver is hypoxia due to the lack of perfusion that can lead to cellular stress [13,14], and secretion of large amounts of ATP (reviewed in [15]). Hypoxia also drives expression of the well-defined transcription factor HIF1 $\alpha$, which promotes the expression of ectoenzymes CD39 (NTPDase1) and CD73 (5'-NT) on tumor cells, stromal cells, and tumor infiltrating immunosuppressive cell subsets such as regulatory T cells (Treg) and myeloid derived suppressor cells (MDSC) [16,17]. CD39 catalyzes the conversion of ATP and ADP into AMP, while CD73 catalyzes the irreversible conversion of AMP into ADO [18] (Figure 1). Supporting their role in inflammation and tumorigenesis, mice deficient in CD39 or CD73 are susceptible to inflammation/autoimmunity and are resistant to tumor growth due to alleviation of ADO-mediated immunosuppression [19-21]. Furthermore, CD39 and CD73 have been shown to be biomarkers of patient outcomes in several tumor types, with the majority of studies linking high expression to poorer clinical outcomes in triple negative breast, lung, ovarian, kidney, gastric cancer, and melanoma. However, other studies have also linked high expression of CD73 with positive outcomes in certain cancers such as bladder or colorectal cancers [22-28]. The reasons for these discrepancies are not fully understood but are potentially related to the relative contribution of the anti-tumor immune response in each cancer type. Tumors that have lower expression of ectonucleotidases may have increased extracellular ATP levels that can play a dual role in the TME by acting on P2 receptors to fine-tune the immune response. ATP can drive the recruitment and activation of inflammatory cells, particularly antigen presenting cells, and increase their capacity to perform antigen presentation but has also been shown to attract Treg cells and promote T-helper $2\left(\mathrm{~T}_{\mathrm{H}} 2\right)$ or Treg cell differentiation which may instead promote an immunosuppressive TME (reviewed in [15]). Although AMP production is thought to be predominantly mediated by CD39, an alternative source of AMP is the conversion of NAD ${ }^{+}$by CD38 and CD203a receptors [29-32] and through the activity of tissue non-specific alkaline phosphatases [33,34]. CD38 is expressed on tumors, $\mathrm{T}$ cells, and NK cells and can promote ADO generation and subsequent suppression of $\mathrm{T}$ cell function and proliferation $[35,36]$. Finally, ADO is rapidly removed from the extracellular space by conversion 
into inosine (INO) by ADO deaminase (ADA) or uptake by nucleoside transporters (NT) back into the cell, whereby it is converted back into AMP by ADO kinases [37]. Thus, ADO accumulates in the TME predominantly through the catabolism of extracellular ATP to ADO by CD73, CD39, and CD38 expressed on tumor and immune cells, and has been reported to mediate suppression of anti-tumor immunity through activation of ADO receptors (Figure 1).

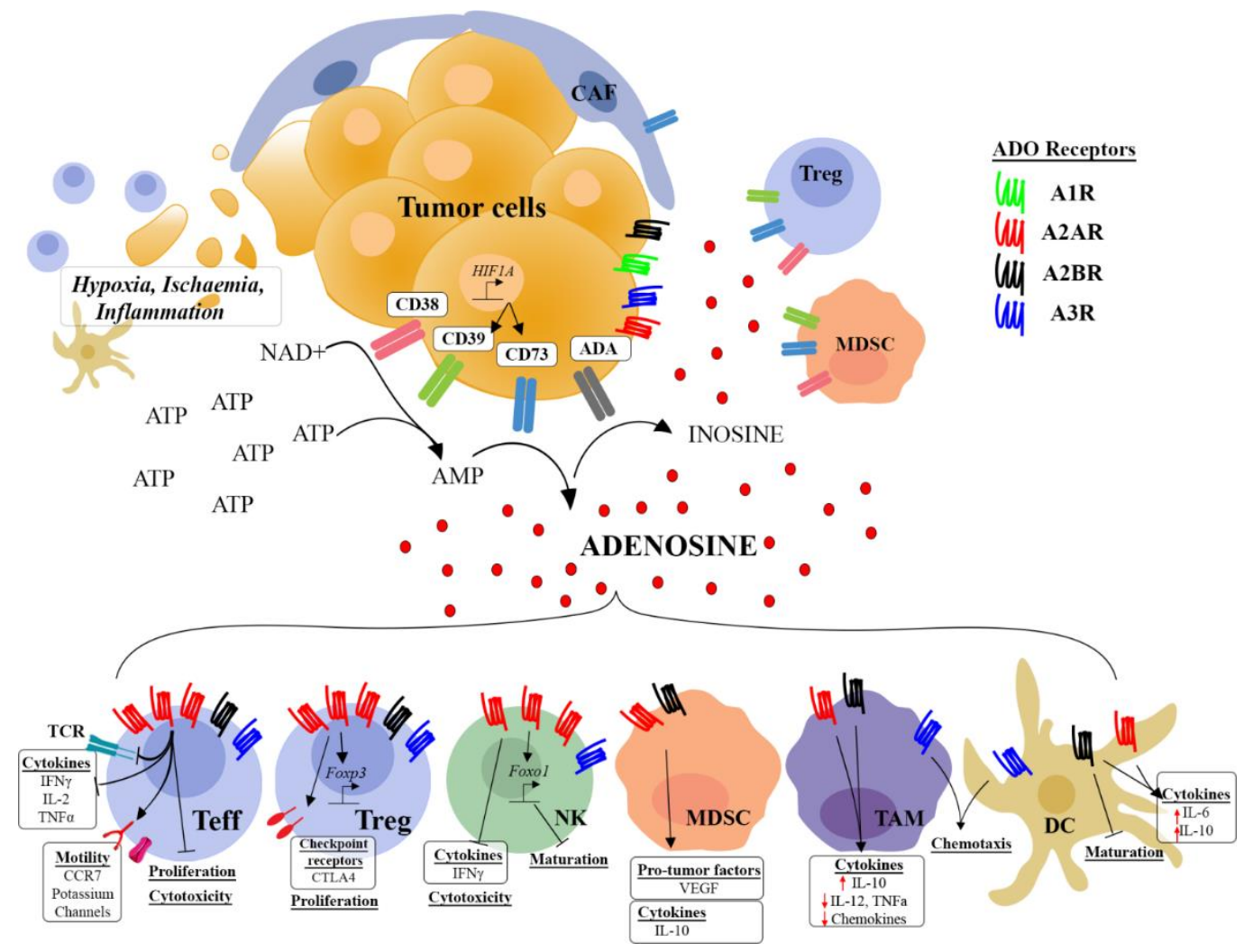

Figure 1. Generation of adenosine in the tumor microenvironment leads to the suppression of multiple immune subsets. Arrows indicate increased expression or activation. T bars indicate inhibition or reduced activity.

\section{The Diversity of Adenosine Receptor Signaling}

The four known subtypes of $A D O$ receptors $\left(A_{1} R, A_{2 A} R, A_{2 B} R\right.$, and $\left.A_{3} R\right)$, all of which are G-protein coupled receptors (GPCRs), have a high degree of homology between human, mouse, and rat orthologues. Protein homology ranges between $85 \%$ to $90 \%$ for each receptor subtype except the $A_{3} R$, which shows the greatest variability between species with only a $78.9 \%$ homology between mouse and human [38]. Endogenous ADO has a potency for the $A_{1} R, A_{2 A} R$, and $A_{3} R$ in the high $\mathrm{nM}$ range. The $\mathrm{A}_{2 \mathrm{~B}} \mathrm{R}$ however is considered a relatively low affinity receptor with a potency in the micromolar range $[39,40]$. Interestingly, the human $A_{3} R$ but not the rat $A_{3} R$ has higher affinity for ADO comparably, with $K_{i}$ of 290 and $6500 \mathrm{nM}$ respectively, which suggests a potential divergence of function between species [39]. Thus, at physiological concentrations of ADO, signaling is primarily mediated via the $A_{2 A} R, A_{1} R$, and $A_{3} R$ with the $A_{2 B} R$ only being activated during elevated levels of $\mathrm{ADO}$ under pathophysiological conditions such as in the inflammatory TME. Although ADO is the predominant ligand for the ADO receptors, INO has also been identified as a possible partial agonist for the $\mathrm{A}_{2 \mathrm{~A}} \mathrm{R}$ and $\mathrm{A}_{3} \mathrm{R}$ indicating that the role of non-canonical ligands for the ADO receptors should also be considered [41-44]. Similar to other GPCRs, ADO receptors can mediate ligand-specific signaling events known as biased agonism [45]. For example, activation of the $\mathrm{A}_{2 \mathrm{~A}} \mathrm{R}$ by INO preferentially promotes extracellular signal-regulated kinases 1 and 2 (ERK1/2) signaling, whereas ADO induced signaling is biased towards cAMP [46]. As many of the ADO receptors are co-expressed on the same 
cell, their signaling pathways can be complex with multiple mechanisms to consider, such as the interplay between regulation of expression, trafficking, and desensitization of ADO receptors [47,48], ligand-receptor interactions (reviewed in [49], receptor-receptor interactions (reviewed in [39]), and the spatial and temporal compartmentalization of signaling (reviewed in $[50,51])$. While these mechanisms undoubtedly play a major role in immune cell regulation and could explain the diversity of cellular responses, they are beyond the scope of this review, and here we will focus on downstream pathways of ADO signaling characterized by individual cell types and their effect, with a focus on tumor cells and tumor-infiltrating immune cell subsets.

GPCRs couple with intracellular signal transducers such as the heterotrimeric G-proteins, which consists of the $G \alpha, G \beta$, and $G \gamma$ subunits. While the $G \alpha$ subunit can signal independently, the $G \beta$ and $G \gamma$ subunits can only signal as obligate dimers $(G \beta \gamma)$. The $G \alpha$ subunit can be classified into 4 major families $(\mathrm{G} \alpha \mathrm{s}, \mathrm{G} \alpha \mathrm{i} / \mathrm{o}, \mathrm{Gq} / 11, \mathrm{G} \alpha 12 / 13)$ and is a primary signaling modality of the $A_{2 A} R, A_{2 B} R$ and the $A_{1} R, A_{3} R$ receptors which couple to the $G \alpha$ s and $G \alpha i$ /o family of $G \alpha$ proteins respectively. In addition to these, the $A_{2 A} R$ also has the capacity to couple to the Golf that has expression limited to the brain, while the $A_{2 B} R$ [52] and the $A_{3} R$ can also bind to the $G q / 11$ proteins that promote phospholipase $C$ (PLC) dependent intracellular $\mathrm{Ca}^{2+}$ signaling $[40,53,54]$. Stimulation of adenylate cyclase (AC) by $G \alpha$ s proteins induced by stimulation of $A_{2 A} R / A_{2 B} R$ in $T$ cells results in the localized accumulation of cyclic AMP (cAMP) in microdomains that occur at the immunological synapse (IS) (reviewed in [55]). cAMP can bind to the regulatory domains on type 1 Protein Kinase A (PKA) targeted to lipid rafts in the IS by Ezrin, an A-kinase binding protein (AKAP) [55]. This results in the phosphorylation of Src kinase, a negative regulator of Lck kinase, a key mediator of T-cell receptor (TCR) signaling activity [56-59]. Other putative cAMP mediators of T cell suppression include EPAC1, that is involved in the direct transfer of cAMP from Treg to effector T cells (Teff) through gap junctions $[60,61]$, and rap1 that suppresses Teff function and is a known downstream pathway of the checkpoint receptor CTLA-4 [62,63]. In addition to suppression of T cell responses, cAMP and PKA have an overall inhibitory effect on other immune cells including B cells, neutrophils [64-66], monocytes/macrophages $[67,68]$, and NK cells [69]. Whilst the $A_{2 A} R$ and $A_{2 B} R$ increase cAMP concentrations, leading to immune cell suppression, the $A_{1} R$ and $A_{3} R$ limit cAMP accumulation through $G \alpha$ i mediated suppression of $A C$ activity. The $A_{1} R$ and $A_{3} R$ can therefore potentially activate opposing signaling pathways in immune cells, exemplified by $A_{1} R$ and $A_{3} R$ specific agonists reversing inhibition of cytokine production and proliferation by the $\mathrm{A}_{2 \mathrm{~A}} \mathrm{R}$ in a mixed lymphocyte culture [70]. $\mathrm{A}_{3} \mathrm{R}$ stimulation has also been shown to suppress cAMP levels in T cells [71,72]. Notably, these studies were performed exclusively with pharmacological agents that are specific for the respective receptors but may still have some activity on the other receptor subtypes and so do not preclude the possibility that these signaling events are exclusively $A_{1} R$ and $A_{3} R$ mediated. Aside from the $G \alpha$ subunit which signals independently, the $G \beta$ and $G \gamma$ subunits can also signal as obligate heterodimers. In addition, $\beta$-Arrestins or AKAPs can interact with the ADO receptors as scaffolding proteins to recruit a host of other signaling proteins that form the signalosome [49]. These proteins include, but are not limited, to mitogen-activated protein kinases (MAPK), PLC, Protein kinase C (PKC), Protein kinase D, RhoA, ERK, PI3K/AKT, or the mTOR proteins [53,73-80]. While a myriad of downstream pathways of $\mathrm{ADO}$ receptor signaling have been identified and suggested to play a role in tumor and immune cell function, many of the signaling pathways are cell type dependent and only a few studies have actually shown a direct link between signaling pathways and phenotypic observations in primary immune cells. Given that these signaling events are determined by a complex interplay governed by the cellular expression of the different ADO receptors as well as the proteins involved in the downstream signaling pathways, it is important to consider these signaling pathways in a cell type specific context.

\section{Expression of Adenosine Receptors and Signaling Pathways in Tumor Cells}

ADO receptors are expressed in hematopoietic and non-hematopoietic tissues and therefore are often expressed in both hematological and non-hematological cancers. In addition, there are several 
reports of tumor expression of all four ADO receptors: $A_{1} R$ [71,81], $A_{2 A} R[28,71,81-83], A_{2 B} R[84,85]$, and $A_{3} R[71,73,86,87]$. Due to the diverse expression of ADO receptors on distinct tumor types (and likely differential signaling induced) it is perhaps unsurprising that a range of phenotypes have been observed following stimulation of tumor cells by ADO. These include diverse effects on proliferation, apoptosis, cytoprotection, and migration (reviewed by [88]). The most extensively studied have been the role of the $A_{3} R$ and $A_{2 B} R$ on cancer cells. $A_{3} R$ has been reported to be upregulated in primary and metastatic tumors (relative to healthy matched tissue) in colorectal cancer and breast cancer $[89,90]$ and some studies have suggested that $A_{3} R$ blockade could be a novel oncology target due to its higher expression on cancer tissues. On the other hand, the ability of $A_{3} R$ activation to reduce tumor proliferation and growth has been shown by numerous groups using tumors derived from sarcomas, melanomas, lymphomas, lung tumors, and prostate cancers [88,91-96]. Indeed, the $A_{3} R$ agonists CL-IBMECA and CF102 have shown promise in vitro by inducing apoptosis in multiple tumor types through the suppression of PKA, ERK, and AKT pathways [80,97-99]. Conversely, it has also been reported that inosine-mediated activation of the $\mathrm{A}_{3} \mathrm{R}$ can enhance melanoma cell proliferation through activation of the ERK pathway [100] and a cytoprotective role for the $A_{3} R$ has also been described [101]. Similarly, activation of the $A_{3} R$ has been suggested to enhance the migration or invasion of tumor cells $[73,102,103]$. Notably, in one study, divergent effects of $A_{3} R$ activation (via IB-MECA stimulation) on proliferation were observed in two colorectal cancer lines. $\mathrm{A}_{3} \mathrm{R}$ activation was shown to decrease the proliferation and survival of HCT-116 cells through the protein phosphatase 2A pathway, whereas the proliferation and survival of HT-29 cells was shown to be enhanced through a reduction in intracellular cAMP levels [104]. This study highlights that the effect of ADO receptor agonism on cancer cell biology may differ depending upon the distinct downstream signaling evoked in different cell types.

$A_{2 B} R$ is the predominant receptor expressed in multiple tumor types with several fold higher expression over normal tissue (reviewed in [105]). A number of studies have shown that $A_{2 B} R$ activation can enhance tumor growth $[84,85,106-108]$ and that targeting $A_{2 B} R$ at the genetic level can reverse this effect $[84,106,108]$. $A_{2 B} R$ activation has also been shown to play a role in the migration and metastasis of tumor cells $[19,108-111]$, due to the ability of $A_{2 B} R$ to induce the epithelial-mesenchymal transition (EMT) through activation of the ERK1/2 pathway [112,113]. Interestingly, Giacomelli et al. [113] demonstrated that the activation of cAMP (mediated through $\mathrm{A}_{2 \mathrm{~B}} \mathrm{R}$ activation) inhibited the EMT and that effects were more pronounced in the presence of a PKA inhibitor. Thus, distinct environmental cues and/or biased agonism may contribute to the net effect of $A_{2 B} R$ expression on tumor cells. $A_{2 B} R$ activation and downstream JunB activation also promoted tumor growth through increased production of VEGF and IL-8, subsequently enhancing angiogenesis $[114,115]$. Taken together, these observations may explain the negative association between $\mathrm{A}_{2 \mathrm{~B}} \mathrm{R}$ expression and patient outcomes in several cancer types including breast and bladder cancer $[108,109]$.

The $A_{2 A} R$ is overexpressed in some cancers, such as head and neck squamous cell carcinoma (HNSCC) $[28,116]$, and in several breast and melanoma cell lines, $[76,82,117]$ and has been shown to induce PLC, PKC, AKT, MAPK/ERK, and JNK signaling pathways to promote cell proliferation in vitro [118]. The ERK and JNK pathways have also been shown to be downstream effectors of $A_{1} R$ signaling, promoting proliferation and migration of tumors [119]. While antagonists to the $A_{2 A} R$ and $A_{1} R$ have been reported to suppress tumor growth in vitro, a definitive role for suppressing tumor growth in vivo remains to be determined. Koszalka et al. performed a broad study on the in vivo effect of $A_{1} R, A_{2 A} R$, and $A_{3} R$ signaling in $B 16$ melanoma in mice and found that the receptors contribute to the TME by modulating angiogenesis, neovascularization, and infiltration of immunosuppressive tumor associated macrophages (TAMs) [76]. Multiple groups have shown that genetic deletion or blockade of the $\mathrm{A}_{2 \mathrm{~A}} \mathrm{R}$ in mice has potent effects in enhancing anti-tumour immunity and reducing tumor growth and metastasis, indicating that targeting the $\mathrm{A}_{2 \mathrm{~A}} \mathrm{R}$ on immune cells likely has a larger therapeutic effect than targeting this receptor on tumor cells alone $[9,110]$. 


\section{Effect of Adenosine on T Cell Responses}

\subsection{Effector T Cells}

Mouse and human $T$ cells express $A_{2 A} R, A_{2 B} R$, and $A_{3} R[72,120,121]$. ADO suppresses the cytokine production and proliferation of both $\mathrm{CD} 8^{+}$and $\mathrm{CD} 4^{+} \mathrm{T}$ cells as well as the cytotoxic activity of CD8 ${ }^{+} T$ cells [122-128]. This is largely thought to be mediated through the activation of the $A_{2 A} R$ as pharmacological blockade of the $A_{2 A} R$ reduces the effects of $A D O$ analogues and $A_{2 A} R^{-/-} T$ cells are resistant to these compounds [129-131]. In vivo, $\mathrm{A}_{2 \mathrm{~A}} \mathrm{R}^{-/-}$or $C D 73^{-/-} \mathrm{T}$ cells exhibit an enhanced inflammatory phenotype [132]. For example, they more profoundly induce colitis [133] and exhibit more potent anti-tumor activity. In the acute setting it is known that the upregulated expression of $\mathrm{A}_{2 \mathrm{~A}} \mathrm{R}$ on $\mathrm{T}$ cells is driven through NFAT/NFKB which are activated downstream of the TCR or HIF1 $\alpha$ in the context of hypoxia [130,134]. Maximal upregulation is seen rapidly $(\sim 4-6 \mathrm{~h}$ post activation) suggesting that activated cells within the hypoxic tumor microenvironment may be immediately sensitized to ADO [135]. Rapid upregulation of the $A_{2 A} R$ is a physiological mechanism to reduce inflammatory tissue damage in multiple organs $[136,137]$, but this pathway is also utilized by tumors to suppress anti-tumor immunity, with increased expression of the $\mathrm{A}_{2 \mathrm{~A}} \mathrm{R}$ being observed on tumor-infiltrating $\mathrm{CD}^{+} \mathrm{T}$ cells relative to those isolated from the draining lymph node [131]. Multiple signaling events have been reported downstream of the $A_{2 A} R$ (Figure 2) but the suppressive effect of $A_{2 A} R$ activation on effector $T$ cells is predominantly thought to be mediated by increased cAMP levels [60,138-140]. However, ADO has also been shown to attenuate signaling through key kinases proximal to the TCR including ZAP-70, ERK1/2, and JunB/AP-1 binding, which has also been associated with suppression of $\mathrm{T}$ cell proliferation and reduced calcium-influx into $\mathrm{CD} 8^{+}$ cells $[122,141,142]$. A role of $A_{2 A} R$ mediated inhibition of STAT5 signaling via Shp-2 as well as CpG site demethylation of the IL-2 promoter have also been described in T cells [142-144]. Whilst the $\mathrm{A}_{2 \mathrm{~A}} \mathrm{R}$ is thought to be the predominant receptor with regards to suppression of $\mathrm{T}$ cell responses, a role for both $A_{2 B} R$ and $A_{3} R$ receptors has also been postulated [121,145]. In contrast to the $A_{2 A} R$, some studies have indicated that signalling via the $\mathrm{A}_{3} \mathrm{R}$ enhances $\mathrm{T}$ cell function $[146,147]$. Although not addressed in these studies, one possible mechanism for this would be that $\mathrm{A}_{3} \mathrm{R}$ activation has been reported to decrease intracellular cAMP levels within T cells [72]. $A_{3} R$ expression can be increased by cAMP levels mediated by activation of $\mathrm{ADO}$ receptors and through $\mathrm{T}$ cell activation, which suggests a potential role in negative feedback to the $A_{2 A} R / A_{2 B} R$ mediated signaling [148].
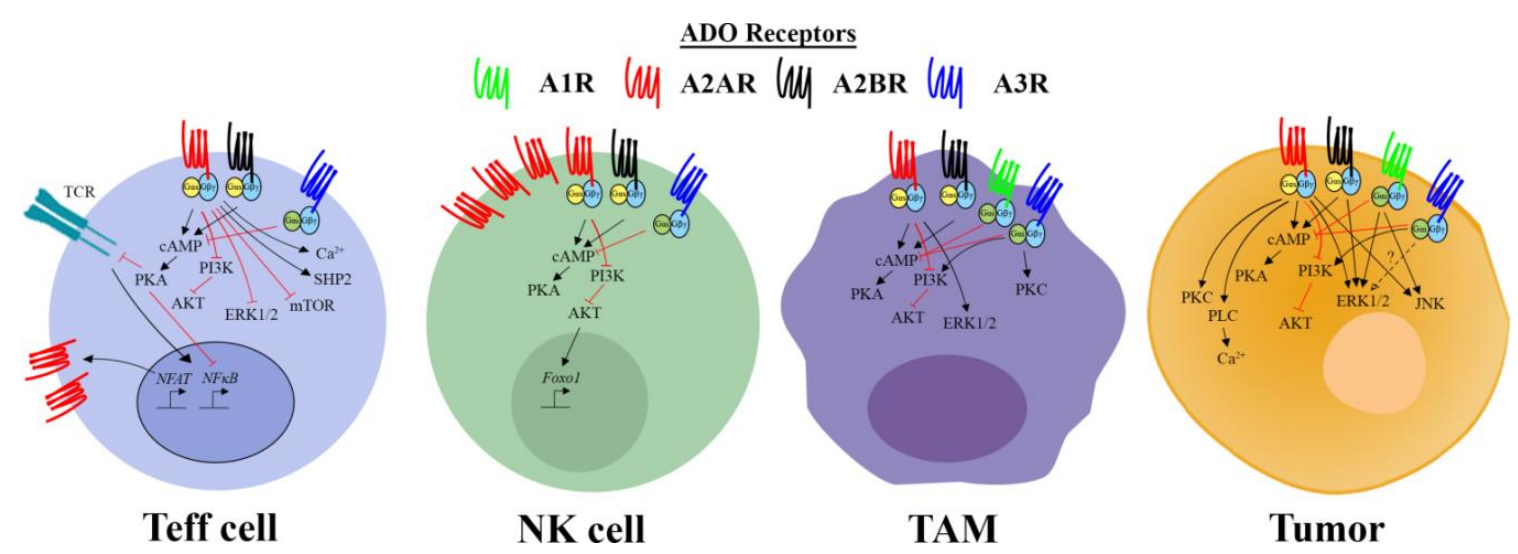

Figure 2. Expression of adenosine receptors and their downstream signalling pathways within various immune cell subsets and tumor cells in the context of the TME. Arrows indicate increased expression or activation. $\mathrm{T}$ bars indicate inhibition or reduced activity.

\subsection{Regulatory $T$ Cells}

While CD73 is expressed on effector T cells, foxp3+ Tregs are capable of co-expressing both CD39 and CD73, and hence contributing to the generation of ADO in the TME and suppression 
of anti-tumor immune response [126]. Interestingly the $\mathrm{A}_{2 \mathrm{~A}} \mathrm{R}$ is also highly expressed on foxp $3^{+}$ Tregs and stimulation of foxp $3^{+}$Tregs with $\mathrm{A}_{2 \mathrm{~A}} \mathrm{R}$ agonists have been reported to result in increased cAMP, proliferation, and induction of foxp3, PD-1, and CTLA-4 expression in vitro [126,149-151]. Indeed, it appears that autocrine adenosine signalling via the $\mathrm{A}_{2 \mathrm{~A}} \mathrm{R}$ expressed on Tregs may also be important in their suppressive function [151]. Supporting this rationale, $\mathrm{A}_{2 \mathrm{~A}} \mathrm{R}$ blockade has been reported to reduce the number of tumor-infiltrating Tregs which may contribute to its anti-tumor efficacy in vivo [116].

\subsection{Regulation of Memory T Cells}

Alternative roles of the $A_{2 A} R$ include reducing $T$ cell motility through the modulation of potassium channels [152], regulation of metabolism, and modulation of memory differentiation through PI3K-AKT pathways [9,122,142,153-155]. Although $\mathrm{A}_{2 \mathrm{~A}} \mathrm{R}$ and $\mathrm{A}_{2 \mathrm{~B}} \mathrm{R}$ are more highly expressed in effector memory cells, their activation is associated with the preservation of a naïve/ central memory phenotype [35]. Activation of $\mathrm{A}_{2 \mathrm{~A}} \mathrm{R} / \mathrm{A}_{2 \mathrm{~B}} \mathrm{R}$ has been shown to promote expression of CCR7 [156] and the IL7R [153] whilst reducing FAS/FASL induced cell death [157], highlighting the importance of $\mathrm{A}_{2 \mathrm{~A}} \mathrm{R}$ signaling in maintaining memory and tolerance. Notably, reduced AMPK/mTOR/pS6 signaling has been identified downstream of $\mathrm{A}_{2 \mathrm{~A}} \mathrm{R}$ activation, with a more pronounced phenotype observed in memory $\mathrm{T}$ cells [35]. Interestingly, a subset of $\mathrm{CD} 8^{+} \mathrm{T}$ cells co-expressing CD39 and CD103 have been identified as being enriched in tumors and correlate with better overall survival in patients with head and neck cancer [158]. These $\mathrm{T}$ cells express a resident memory $\mathrm{T}$ cell gene signature and high levels of exhaustion markers, and blockade of CD39/CD73 alone or combination with checkpoint blockade may be a promising therapeutic strategy to improve the anti-tumor potency of these $\mathrm{CD} 103^{+} \mathrm{CD} 39^{+}$ $\mathrm{T}$ cells [158]. Co-expression of CD38 and CD101 has also been identified as a phenotypic indicator of terminally differentiated PD1 ${ }^{\text {hi }} \mathrm{T}$ cells, which were not responsive to checkpoint blockade [159]. The role of CD39, CD38, and ADO itself in the differentiation of these cells is yet to be demonstrated but these observations suggest that $\mathrm{ADO}$ modulates $\mathrm{T}$ cell differentiation as well as activity in the TME.

\section{Effect of Adenosine on Natural Killer or Natural Killer T Cell Responses}

Natural Killer (NK) and Natural Killer T cells (NKT) express high levels of the $\mathrm{A}_{2 \mathrm{~A}} \mathrm{R}$. Indeed, on a per cell basis NK cells express more $A_{2 A} R$ mRNA than $T$ cells during homeostasis $[160,161]$. NK cells from wild-type mice, but not $A_{2 A} R^{-/-}$mice can be potently suppressed by $A D O$ or specific $A_{2 A} R$ agonists in terms of their cytotoxic function and cytokine production. Similarly to T cells, expression of the $A_{2 A} R$ on NK cells is more abundant on the more mature NK subsets (CD56 ${ }^{\mathrm{dim}}$ ) as opposed to the immature $\mathrm{CD} 56^{\text {high }}$ precursor population and $\mathrm{A}_{2 \mathrm{~A}} \mathrm{R}$ blockade has been shown to enhance NK cell maturation $[58,110,162-164]$. Similarly to T cells, $A_{2 A}$ R-mediated enhancement of intracellular cAMP concentration and PKA signaling is thought to be the predominant mechanism by which ADO suppresses NK and NKT cell activity (Figure 2) [163,165]. At the transcriptional level, this may be related to observations that $\mathrm{A}_{2 \mathrm{~A}} \mathrm{R}$ signaling induces foxo- 1 expression by inhibiting AKT. Since foxo- 1 deficient NK cells have been shown to exhibit an enhanced maturation phenotype, it is possible that the upregulation of foxo- 1 by $\mathrm{A}_{2 \mathrm{~A}} \mathrm{R}$ activation limits the maturation and effector functions of $\mathrm{NK}$ cells [166]. As with T cells, NK cells also express the $A_{3} R$ and their function has been shown to be positively regulated by $\mathrm{A}_{3} \mathrm{R}$ agonists resulting in inhibition of primary and metastatic tumor growth in mouse and human models of colon cancer and melanoma [147,167-169].

\section{Effect of Adenosine on Myeloid Cells}

Myeloid cells are highly heterogeneous within the tumor microenvironment and are an important determinant in shaping the anti-tumor immune response. Immature myeloid cells, including myeloid-derived suppressor cells (MDSCs) and "type 2" (M2) macrophages have the potential to suppress $\mathrm{T}$ cells through a range of mechanisms, including ADO production via their expression of CD73 and CD39 [170,171]. $A_{2 A} R$ and $A_{2 B} R$ are also expressed on a range of myeloid cells and their 
activation has been shown to modulate the function of monocytes, macrophages, and DCs [172] and promote the expansion of MDSCs [173]. Although the mechanisms by which the expression of the $A_{2 A} R$ is controlled on myeloid cells remains to be elucidated, the expression of the $A_{2 B} R$ was shown to be increased following IFN $\gamma$ stimulation and by hypoxia under the control of the HIF1 $\alpha$ transcription factor $[174,175]$. Furthermore, it has been demonstrated that TGF $\beta$ enhances the expression of CD73 and CD39 on MDSCs [176]. Therefore, the CD73: $A_{2 A} R / A_{2 B} R$ axis may be an important mechanism of immune modulation by MDSC and TAMs in the context of the TME.

Activation of $A_{2 A} R$ or $A_{2 B} R$ has also been shown to enhance the differentiation of alternatively activated macrophages, as shown by the upregulation of several M2 markers including TIMP-1 and arginase 1 [177]. $\mathrm{A}_{2 \mathrm{~A}} \mathrm{R}$ signaling promotes ERK, pAKT, and pSTAT3 in monocytes, leading to enhanced differentiation of M2 macrophages in the TME and increased release of pro-tumorigenic cytokines and factors [155]. Similarly, activation of the $\mathrm{A}_{2 \mathrm{~B}} \mathrm{R}$ and potentially other $\mathrm{ADO}$ receptors on DCs was shown to impair DC maturation [178] and induce a tolerogenic phenotype with reduced CD8 ${ }^{+} \mathrm{T}$ cell priming capacity $[179,180]$. $\mathrm{A}_{2 \mathrm{~B}} \mathrm{R}$ activation has also been shown to enhance IL-6 production from DCs, and to consequently promote $\mathrm{T}_{\mathrm{H}} 17$ responses [181], the effect of which in cancer is controversial [182]. In the acute setting, activation of $\mathrm{A}_{2 \mathrm{~A}} \mathrm{R}$ or $\mathrm{A}_{2 \mathrm{~B}} \mathrm{R}$ has been shown to suppress pro-inflammatory cytokine production by monocytes [67], macrophages [183], and DCs [184-186]. Thus, macrophages stimulated with ADO secrete increased amounts of IL-10 and less IL-12, TNF $\alpha$, and chemotactic factors. [183,187-189]. Using an elegant approach in which the $A_{2 A} R$ was specifically deleted in myeloid cells (using a Lys-Cre system) Cekic et al. were able to show that the $\mathrm{A}_{2 \mathrm{~A}} \mathrm{R}$ limited anti-tumor immune responses in part through modulation of myeloid cells and subsequent enhancement of anti-tumor $\mathrm{T}$ cell responses [190]. Similarly, $\mathrm{A}_{2 \mathrm{~B}} \mathrm{R}$ blockade has been shown to enhance anti-tumor immune responses, partly through a reduction in MDSC differentiation $[115,173,191]$ and partly through an enhancement of the capacity of DCs to evoke anti-tumor T cell responses [172,191].

$\mathrm{A}_{3} \mathrm{R}$ activation has been associated with increased chemotaxis, degranulation and regulation of superoxide production in neutrophils [192-195], plasmacytoid DCs and monocytes/macrophages [78,196-198]. A ${ }_{3}$ R expression in intratumoral mast cells is associated with PI3K mediated phosphorylation of ERK/MAPK and AKT resulting in increased release of IL-8 that can promote angiogenesis and EMT in tumor cells [199]. The PI3K and PKC signaling pathway has also been associated with $A_{3} R$ in macrophages and has been shown to enhance TNF $\alpha$ release in response to LPS, indicating a possible role of $\mathrm{A}_{3} \mathrm{R}$ in regulating inflammatory cytokine release [78]. The $A_{3} R$ may thus be involved in the recruitment, survival, and function of macrophages and mast cells in the TME $[76,200]$.

Taken together, these observations suggest that ADO plays an important role in modulating the activity of tumor-infiltrating myeloid cells by limiting their capacity to evoke anti-tumor immune responses and are potential targets for therapeutic intervention.

\section{Targeting the Adenosine Pathway in TME to Improve Immunotherapies}

Cancer immunotherapies have been hailed as the fourth pillar of cancer treatment and its great success in the clinic has led to the Nobel prize recently being awarded to James Allison and Tasuku Honjo for recognition of their discovery of the checkpoint molecules CTLA-4 and PD-1 respectively. Checkpoint receptor blockade can lead to durable responses in a range of cancers, however not all patients respond to treatment, highlighting the need for further research to understand tumor evasion mechanisms and identify other targets that can overcome these 'brakes' on the immune response. As described in previous sections, $\mathrm{ADO}$ is known to act through the $\mathrm{A}_{2 \mathrm{~A}} \mathrm{R}$ to negatively regulate $\mathrm{T}$ and NK cell responses in the TME and naturally targeting this pathway may further enhance the efficacy of immunotherapies in the clinic.

Seminal studies from the Sitkovsky and Powell groups demonstrated that the genetic deletion of the $A_{2 A} R$ can potently enhance anti-tumor responses in mice due to the activation or enhancement of $\mathrm{T}$ cells in the TME $[9,201]$. This has led to attempts from multiple groups to therapeutically target 
this pathway. The main targets for this pathway are the ectoenzymes CD73, CD39, and CD38 which promote $\mathrm{ADO}$ formation, and also the downstream $\mathrm{A}_{2 \mathrm{~A}} \mathrm{R}$. The potential of targeting $\mathrm{CD} 73$ was shown by the observation that reducing the expression of CD73 in the ID8-ova ovarian tumor cell line increased their susceptibility to $\mathrm{T}$ cell mediated killing in vitro and in vivo. Similarly, anti-CD73 antibodies were shown to reduce tumor growth and metastasis through activation of NK and T cell responses $[19,20,125]$. These effects in the primary tumor setting were shown to be $\mathrm{T}$ cell dependent, with the efficacy of anti-CD73 being lost in mice lacking T cells. Interestingly, the dual blockade of CD73 and the $\mathrm{A}_{2 \mathrm{~A}} \mathrm{R}$ has been reported to elicit improved anti-tumor effects. This may be because tumors increased their expression of $C D 73$ in $A_{2 A} R^{-/-}$mice and in response to $A_{2 A} R$ inhibition, potentially highlighting the importance of CD73 as an escape mechanism to anti-tumor T cell responses [202,203]. Considering the immunosuppressive role of $\mathrm{A}_{2 \mathrm{~A}} \mathrm{R}$ on $\mathrm{T}$ and $\mathrm{NK}$ cells, rational combination strategies targeting the ADO pathway with checkpoint inhibitors and adoptive cell therapies (ACT) have the potential to synergistically enhance anti-tumour immune cell function. CD73, and more recently CD38, expression on tumor cells have been shown to confer resistance to anti-PD-1, as activation of $\mathrm{T}$ cells and PD-1 blockade upregulates the expression of $\mathrm{A}_{2 \mathrm{~A}} \mathrm{R}$, making these cells more susceptible to adenosine-mediated suppression [131]. Hence inhibition of $C D 73, \mathrm{~A}_{2 \mathrm{~A}} \mathrm{R}$ or $\mathrm{CD} 38$ in combination with anti-PD-1, has been shown to elicit enhanced anti-tumour $\mathrm{T}$ cell responses mediated by enhanced IFN $\gamma$ and Granzyme B expression by CD8 ${ }^{+} \mathrm{T}$ cells $[131,204,205]$. Another study demonstrated that $\mathrm{A}_{2 \mathrm{~A}} \mathrm{R}^{-/-} \mathrm{T}$ cells could better penetrate hypoxic tumors, which could then be targeted with dual checkpoint blockade to further enhance anti-tumor function [13]. Although the majority of combination approaches have focused on the ability of ADO targeting to enhance T cell responses, other immune subsets within the TME can also be enhanced by targeting the ADO axis including NK cells [110] and therefore future combination approaches may explore reagents which stimulate other immune cell subsets modulated by ADO. Similarly, this strategy can potentially be applied to ACT and chimeric antigen receptor $\mathrm{T}$ cell therapy (CAR-T), whereby tumor specific autologous TILs are extracted, expanded ex-vivo with or without modifications before reinfusion back into the patient in large numbers. Indeed, it has been demonstrated that targeting the $\mathrm{A}_{2 \mathrm{~A}} \mathrm{R}$ using genetic or pharmacological approaches could enhance the efficacy of CAR T cells or conventional ACT [125,128,206,207].

Chemotherapy remains a major front-line option for many cancer patients, and it is now well accepted that the immune response is a major determinant governing the response to treatment. Therefore, there is huge potential for synergy by combining $A_{2 A} R$ antagonists or anti-CD73/ anti-CD39 with chemotherapy. Evidence suggests that the ADO axis is enhanced following chemotherapy and modulates the therapeutic response. For example, an anthracycline-based chemotherapeutic agent, doxorubicin (DOX), was shown to induce CD73 expression on tumor cells [24]. Another recent study demonstrated an increase in CD73 and PD-L1 expression by DOX, gemcitabine, or paclitaxel chemotherapy mediated by increased expression of HIF1 $\alpha$ and HIF2 $\alpha$ [208]. As such, blocking CD73 or $\mathrm{A}_{2 \mathrm{~A}} \mathrm{R}$ directly or through inhibition of HIF and subsequent expression of these receptors can significantly enhance anthracycline-based chemotherapy and may be viable as a future combinatorial strategy in the clinic [24].

Multiple small molecule inhibitors and antagonistic antibodies against these targets have been developed and show promising therapeutic efficacy against different solid tumors in clinical trials (Table 1). $\mathrm{A}_{2 \mathrm{~A}} \mathrm{R}$ antagonists SYN115 and Istradefylline have been trialed to improve motor function in patients with Parkinson's disease and are well tolerated with the most common adverse effects being dyskinesia, nausea, and dizziness $[209,210]$. Other $\mathrm{A}_{2 \mathrm{~A}} \mathrm{R}$ antagonists are being trialed to treat cancer, which include CPI-444 (NCT02655822, NCT03454451), PBF509 (NCT02403193), NIR178 (NCT03207867), and AZD4635 (NCT02740985, NCT03381274). CPI-444 in combination with anti-PD-1 and anti-CTLA4 was highly effective in promoting $\mathrm{CD} 8^{+} \mathrm{T}$ cell responses and eliminating tumors in a preclinical model [211]. Together these preclinical findings have led to the $\mathrm{A}_{2 \mathrm{~A}} \mathrm{R}$ antagonists PBF-509 (NCT02403193) and CPI-444 (NCT03337698) being trialed for safety and efficacy against HNSCC, NSCLC, melanoma, renal cell cancer, triple-negative breast cancer (TNBC), colorectal, bladder, 
and prostate cancers [212]. Antibodies targeting CD73 have also progressed to early stage clinical trials, both alone and in combination with anti-PD-1 or antagonists of the $\mathrm{A}_{2 \mathrm{~A}} \mathrm{R}$ (NCT02503774, NCT03267589, NCT03616886, NCT03381274, NCT03454451, NCT03549000, NCT02754141). Similarly, two antibodies targeting CD38 have been developed, Daratumumab (NCT02944565) and isatuximab (NCT01084252), and have been trialed in multiple myeloma. Based on the observations aforementioned that CD38 may be a key mediator of resistance to checkpoint blockade, these potential combinations in the solid tumor setting warrant investigation.

Table 1. Ongoing or upcoming clinical trials targeting the adenosine pathway.

\begin{tabular}{|c|c|c|c|c|c|c|}
\hline Target & Drug & Company & $\begin{array}{c}\text { Clinical Trial } \\
\text { Number }\end{array}$ & $\begin{array}{l}\text { Study } \\
\text { Phase }\end{array}$ & Cancer Type & Combination \\
\hline $\begin{array}{c}\mathrm{A}_{2 \mathrm{~B}} \mathrm{R} \\
\text { (Antagonist) }\end{array}$ & PBF-1129 & Palobiofarma & NCT03274479 & I & NSCLC & \\
\hline \multirow{2}{*}{$\begin{array}{c}\mathrm{A}_{2 \mathrm{~A}} \mathrm{R} \\
\text { (Antagonist) }\end{array}$} & CPI-444 & Corvus & NCT03337698 & $\mathrm{I} / \mathrm{II}$ & Carcinoma, NSCLC & Multiple drug combinations \\
\hline & PBF-509 & Palobiofarma & NCT02403193 & I/II & NSCLC & PDR-001 ( $\alpha$ PD-1) \\
\hline $\begin{array}{c}\mathrm{A}_{3} \mathrm{R} \\
\text { (Agonist) }\end{array}$ & CF-102 & CanFite BioPharma & NCT02128958 & II & Hepatocellular carcinoma & \\
\hline \multirow{5}{*}{ CD73 } & \multirow{2}{*}{ MEDI-9447 } & \multirow{2}{*}{ MedImmune } & NCT02503774 & I & Solid cancers & Durvalumab ( $\alpha$ PD-L1) \\
\hline & & & NCT03267589 & II & Ovarian cancer & $\begin{array}{l}\text { Durvalumab ( } \alpha \text { PD-L1), Tremelilumab } \\
\quad(\alpha \text { CTLA4), MEDI } 0562(\alpha \text { OX-40) }\end{array}$ \\
\hline & CPI-006 & Corvus & NCT03454451 & I & Solid cancers & $\begin{array}{l}\text { Pembrolizumab ( } \alpha \text { PD-L1), } \\
\text { CPI-444 }\left(\mathrm{A}_{2 \mathrm{~A}} \mathrm{Ri}\right)\end{array}$ \\
\hline & NZV-930 & Norvatis & NCT03549000 & I & Solid cancers & PDR001 ( $\alpha$ PD-1), PBF-509 (A2A Ri) \\
\hline & BMS-986179 & Bristol-Meyers-Squibb & NCT02754141 & $\mathrm{I} / \mathrm{II}$ & Solid cancers & Nivolumab, rHuPH20 \\
\hline
\end{tabular}

Although the majority of clinical development targeting ADO receptors has focused on the $A_{2 A} R$, reagents targeting the alternative $A D O$ receptors are also of interest. Blocking the $A_{2 B} R$ receptor has been shown to inhibit melanoma, prostate, and breast cancer growth in mice and to reduce tumor metastasis $[106,109,213]$. In the clinic, the $A_{2 B} R$ antagonist PBF1129 is currently being trialed in patients with non-small cell lung cancer (NSCLC) (NCT03274479). $\mathrm{A}_{2 \mathrm{~B}} \mathrm{R}$ targeting has a potential dual benefit of limiting tumor cell growth and metastasis as well as enhancing anti-tumor immune responses through modulation of both lymphoid and myeloid subsets. Interestingly, dual $A_{2 B} R / A_{2 A} R$ antagonists have now been developed with the potential to further enhance anti-tumor effects. The $A_{1} R$ and $A_{3} R$ are other potential ADO receptors which could be targeted, but while the $A_{1} R$ antagonist, DPCPX has been shown preclinically to inhibit tumor cell proliferation, migration, and promote apoptosis, no drugs targeting the $\mathrm{A}_{1} \mathrm{R}$ are currently undergoing clinical trials. Currently there is only one $A_{3} R$ agonist, $C F 102$, undergoing clinical trials to treat hepatocellular carcinoma (NCT00790218, NCT02128958). Further preclinical studies are required to elucidate the potential for combining $A_{1} R$ or $\mathrm{A}_{3} \mathrm{R}$ agonists/antagonists with chemo- or immunotherapies.

\section{Conclusions}

Escaping immune destruction is one of the hallmarks of cancer and overcoming suppressive mechanisms in the tumor niche is a major focus for enhancing immunotherapies. ADO, a metabolite of the ubiquitous energy molecule ATP, is one such mechanism shown to have broad immunosuppressive activities. Reflecting the important role of ADO in the tumor context, CD39, CD73, and CD38 ectoenzymes have been identified as potential biomarkers for clinical outcomes in chemo- and immune-therapies and to identify immune subsets that may be responsible for immunosuppression or are in an exhausted state. Moreover, clinical grade reagents targeting these ectoenzymes, along with the downstream $A D O$ receptors $A_{2 A} R$ and $A_{2 B} R$ have now entered clinical trials alone 
or in combination with other immunotherapy approaches. Several challenges remain in targeting the adenosine immunosuppressive pathway. Firstly, although mice deficient for members of this pathway, including CD73, CD39, and $\mathrm{A}_{2 \mathrm{~A}} \mathrm{R}$, exhibit mild autoimmune phenotypes compared to mice lacking other immune checkpoints such as PD-1 and CTLA-4, the potential remains for unwanted autoimmune/inflammatory side-effects. Moreover, given the ubiquitous expression of adenosine receptors in many cell subtypes the potential for on-target side effects exists. Despite the development of clinical reagents, the underlying mechanisms of these therapies are relatively unknown, particularly in terms of the signaling events mediated by ADO in distinct immune cell subtypes. Understanding of this is hampered by a lack of studies investigating ADO receptor signaling events in primary immune cells. This is likely to be a focus of future studies given that the outcome of ADO receptor activation is dependent on the cell-specific expression of signaling proteins including receptor subtypes as well as downstream signaling molecules. We have summarized the signaling events that have been verified in each of the respective primary immune subsets in Figure 2. In addition, much of the information about ADO receptor signaling has been derived using pharmacological agents which are considered to selectively activate/block certain ADO receptor subtypes. The conclusions from studies like this are potentially confounded as other studies have shown that ADO receptor ligands can also mediate ADO receptor independent effects [214]. Thus, validation of signaling events should be ideally confirmed at the genetic level in primary immune cells. Nevertheless, the overall evidence speaks for the high therapeutic potential of targeting the ADO axis, and further studies which provide further mechanistic insight into this are likely to present the potential for more rational therapeutic combinations.

The inflammatory and hypoxic tumour microenvironment drives the expression of the ectoenzymes CD39, CD73, and CD38 on tumors, cancer associated fibroblasts (CAFs), regulatory $\mathrm{T}$ cells (Treg), and myeloid derived suppressor cells (MDSCs), which catalyze the conversion of ATP and $\mathrm{NAD}^{+}$into extracellular adenosine. Adenosine is rapidly converted to inosine by adenosine deaminase (ADA) expressed on the cell surface. Adenosine and inosine signal through multiple adenosine receptor subtypes $\left(A_{1} R, A_{2 A} R, A_{2 B} R\right.$, and $\left.A_{3 R}\right)$, with $A_{2 A} R$ and $A_{2 B} R$ playing a predominant role in the suppression of anti-tumor immune cell responses. The $A_{2 A} R$ is highly expressed on $T$ effectors (Teff), natural killers (NK), and Tregs relative to the other receptor subtypes. Adenosine modulates multiple functions of tumor infiltrating Teff, Tregs, NKs, MDSCs, tumor associated macrophages (TAM), and dendritic cells (DCs) including differentiation, proliferation, cytokine production, and cytotoxic function.

A summary of the identified signaling pathways downstream of the $A_{1} R, A_{2 A} R, A_{2 B} R$, and $A_{3} R$ in T effectors (Teff), Natural Killer (NK), tumor associated macrophages (TAM), and the tumor cells themselves is presented. The $A_{1} R$ and $A_{3} R$ are coupled to the $G \alpha i$ /o subunit and inhibit adenylate cyclase and cyclic adenosine monophosphate (cAMP) production while the $A_{2 A} R$ and $A_{2 B} R$ are coupled to the $\mathrm{G} \alpha$ s which promote cAMP accumulation. Protein kinase A (PKA), extracellular signal-regulated kinases 1 and 2 (ERK1/2), protein kinase B (AKT), phospholipase C (PLC), phosphatidylinositide 3-kinase (PI3K), protein kinase C (PKC), c-Jun N-terminal kinases (JNK), SHP-2, and the mechanistic target of rapamycic (mTOR) can signal downstream of the adenosine receptors to regulate cell specific responses in the TME.

Funding: P.A.B. is supported by a National Breast Cancer Foundation Fellowship (ID\# ECF-17-005). P.K.D. is supported by an NHMRC Senior Research Fellowship (APP1136680).

Conflicts of Interest: The authors declare no conflict of interest. 


\section{References}

1. Morciano, G.; Sarti, A.C.; Marchi, S.; Missiroli, S.; Falzoni, S.; Raffaghello, L.; Pistoia, V.; Giorgi, C.; Di Virgilio, F.; Pinton, P. Use of luciferase probes to measure ATP in living cells and animals. Nat. Protoc. 2017, 12, 1542-1562. [CrossRef] [PubMed]

2. Ballarin, M.; Fredholm, B.B.; Ambrosio, S.; Mahy, N. Extracellular levels of adenosine and its metabolites in the striatum of awake rats: Inhibition of uptake and metabolism. Acta Physiol. Scand. 1991, 142, 97-103. [CrossRef] [PubMed]

3. Idzko, M.; Ferrari, D.; Eltzschig, H.K. Nucleotide signalling during inflammation. Nature 2014, 509, $310-317$. [CrossRef] [PubMed]

4. Burnstock, G.; Knight, G.E. The potential of P2X7 receptors as a therapeutic target, including inflammation and tumour progression. Purinergic Signal. 2018, 14, 1-18. [CrossRef] [PubMed]

5. Galluzzi, L.; Buque, A.; Kepp, O.; Zitvogel, L.; Kroemer, G. Immunogenic cell death in cancer and infectious disease. Nat. Rev. Immunol. 2017, 17, 97-111. [CrossRef] [PubMed]

6. Ramkumar, V.; Hallam, D.M.; Nie, Z. Adenosine, oxidative stress and cytoprotection. Jpn. J. Pharmacol. 2001, 86, 265-274. [CrossRef] [PubMed]

7. Shaikh, G.; Cronstein, B. Signaling pathways involving adenosine A2A and A2B receptors in wound healing and fibrosis. Purinergic Signal. 2016, 12, 191-197. [CrossRef]

8. Blay, J.; White, T.D.; Hoskin, D.W. The extracellular fluid of solid carcinomas contains immunosuppressive concentrations of adenosine. Cancer Res. 1997, 57, 2602-2605.

9. Ohta, A.; Gorelik, E.; Prasad, S.J.; Ronchese, F.; Lukashev, D.; Wong, M.K.; Huang, X.; Caldwell, S.; Liu, K.; Smith, P.; et al. A2A adenosine receptor protects tumors from antitumor T cells. Proc. Natl. Acad. Sci. USA 2006, 103, 13132-13137. [CrossRef]

10. Kishore, B.K.; Robson, S.C.; Dwyer, K.M. CD39-adenosinergic axis in renal pathophysiology and therapeutics. Purinergic Signal. 2018, 14, 109-120. [CrossRef]

11. Ledderose, C.; Liu, K.; Kondo, Y.; Slubowski, C.J.; Dertnig, T.; Denicolo, S.; Arbab, M.; Hubner, J.; Konrad, K.; Fakhari, M.; et al. Purinergic P2X4 receptors and mitochondrial ATP production regulate T cell migration. J. Clin. Investig. 2018, 128, 3583-3594. [CrossRef] [PubMed]

12. Bradford, K.L.; Moretti, F.A.; Carbonaro-Sarracino, D.A.; Gaspar, H.B.; Kohn, D.B. Adenosine Deaminase (ADA)-Deficient Severe Combined Immune Deficiency (SCID): Molecular Pathogenesis and Clinical Manifestations. J. Clin. Immunol. 2017, 37, 626-637. [CrossRef]

13. Hatfield, S.M.; Kjaergaard, J.; Lukashev, D.; Schreiber, T.H.; Belikoff, B.; Abbott, R.; Sethumadhavan, S.; Philbrook, P.; Ko, K.; Cannici, R.; et al. Immunological mechanisms of the antitumor effects of supplemental oxygenation. Sci. Transl. Med. 2015, 7, 277ra30. [CrossRef] [PubMed]

14. Wang, Y.J.; Fletcher, R.; Yu, J.; Zhang, L. Immunogenic effects of chemotherapy-induced tumor cell death. Genes Dis. 2018, 5, 194-203. [CrossRef]

15. Di Virgilio, F.; Sarti, A.C.; Falzoni, S.; De Marchi, E.; Adinolfi, E. Extracellular ATP and P2 purinergic signalling in the tumour microenvironment. Nat. Rev. Cancer 2018, 18, 601-618. [CrossRef]

16. Allard, D.; Chrobak, P.; Allard, B.; Messaoudi, N.; Stagg, J. Targeting the CD73-adenosine axis in immuno-oncology. Immunol. Lett. 2018. [CrossRef] [PubMed]

17. Maj, T.; Wang, W.; Crespo, J.; Zhang, H.; Wang, W.; Wei, S.; Zhao, L.; Vatan, L.; Shao, I.; Szeliga, W.; et al. Oxidative stress controls regulatory $\mathrm{T}$ cell apoptosis and suppressor activity and PD-L1-blockade resistance in tumor. Nat. Immunol. 2017, 18, 1332-1341. [CrossRef]

18. Antonioli, L.; Blandizzi, C.; Pacher, P.; Hasko, G. Immunity, inflammation and cancer: A leading role for adenosine. Nat. Rev. Cancer 2013, 13, 842-857. [CrossRef]

19. Stagg, J.; Divisekera, U.; McLaughlin, N.; Sharkey, J.; Pommey, S.; Denoyer, D.; Dwyer, K.M.; Smyth, M.J. Anti-CD73 antibody therapy inhibits breast tumor growth and metastasis. Proc. Natl. Acad. Sci. USA 2010, 107, 1547-1552. [CrossRef]

20. Stagg, J.; Divisekera, U.; Duret, H.; Sparwasser, T.; Teng, M.W.; Darcy, P.K.; Smyth, M.J. CD73-deficient mice have increased antitumor immunity and are resistant to experimental metastasis. Cancer Res. 2011, 71, 2892-2900. [CrossRef] 
21. Tsukamoto, H.; Chernogorova, P.; Ayata, K.; Gerlach, U.V.; Rughani, A.; Ritchey, J.W.; Ganesan, J.; Follo, M.; Zeiser, R.; Thompson, L.F.; et al. Deficiency of CD73/ecto-5'-nucleotidase in mice enhances acute graft-versus-host disease. Blood 2012, 119, 4554-4564. [CrossRef] [PubMed]

22. Leone, R.D.; Emens, L.A. Targeting adenosine for cancer immunotherapy. J. Immunother. Cancer 2018, 6, 57. [CrossRef] [PubMed]

23. Buisseret, L.; Pommey, S.; Allard, B.; Garaud, S.; Bergeron, M.; Cousineau, I.; Ameye, L.; Bareche, Y.; Paesmans, M.; Crown, J.P.A.; et al. Clinical significance of CD73 in triple-negative breast cancer: Multiplex analysis of a phase III clinical trial. Ann. Oncol. 2018, 29, 1056-1062. [CrossRef] [PubMed]

24. Loi, S.; Pommey, S.; Haibe-Kains, B.; Beavis, P.A.; Darcy, P.K.; Smyth, M.J.; Stagg, J. CD73 promotes anthracycline resistance and poor prognosis in triple negative breast cancer. Proc. Natl. Acad. Sci. USA 2013, 110, 11091-11096. [CrossRef] [PubMed]

25. Jiang, T.; Xu, X.; Qiao, M.; Li, X.; Zhao, C.; Zhou, F.; Gao, G.; Wu, F.; Chen, X.; Su, C.; et al. Comprehensive evaluation of NT5E/CD73 expression and its prognostic significance in distinct types of cancers. BMC Cancer 2018, 18, 267. [CrossRef] [PubMed]

26. Inoue, Y.; Yoshimura, K.; Kurabe, N.; Kahyo, T.; Kawase, A.; Tanahashi, M.; Ogawa, H.; Inui, N.; Funai, K.; Shinmura, K.; et al. Prognostic impact of CD73 and A2A adenosine receptor expression in non-small-cell lung cancer. Oncotarget 2017, 8, 8738-8751. [CrossRef] [PubMed]

27. Vijayan, D.; Young, A.; Teng, M.W.L.; Smyth, M.J. Targeting immunosuppressive adenosine in cancer. Nat. Rev. Cancer 2017, 17, 709-724. [CrossRef]

28. Vogt, T.J.; Gevensleben, H.; Dietrich, J.; Kristiansen, G.; Bootz, F.; Landsberg, J.; Goltz, D.; Dietrich, D. Detailed analysis of adenosine A2a receptor (ADORA2A) and CD73 (5'-nucleotidase, ecto, NT5E) methylation and gene expression in head and neck squamous cell carcinoma patients. Oncoimmunology 2018, 7, e1452579. [CrossRef]

29. Horenstein, A.L.; Chillemi, A.; Zaccarello, G.; Bruzzone, S.; Quarona, V.; Zito, A.; Serra, S.; Malavasi, F. A CD38/CD203a/CD73 ectoenzymatic pathway independent of CD39 drives a novel adenosinergic loop in human T lymphocytes. Oncoimmunology 2013, 2, e26246. [CrossRef]

30. Horenstein, A.L.; Chillemi, A.; Quarona, V.; Zito, A.; Roato, I.; Morandi, F.; Marimpietri, D.; Bolzoni, M.; Toscani, D.; Oldham, R.J.; et al. NAD(+)-Metabolizing Ectoenzymes in Remodeling Tumor-Host Interactions: The Human Myeloma Model. Cells 2015, 4, 520-537. [CrossRef]

31. Chen, L.; Diao, L.; Yang, Y.; Yi, X.; Rodriguez, B.L.; Li, Y.; Villalobos, P.A.; Cascone, T.; Liu, X.; Tan, L.; et al. CD38-Mediated Immunosuppression as a Mechanism of Tumor Cell Escape from PD-1/PD-L1 Blockade. Cancer Discov. 2018, 8, 1156-1175. [CrossRef] [PubMed]

32. Vaisitti, T.; Audrito, V.; Serra, S.; Bologna, C.; Brusa, D.; Malavasi, F.; Deaglio, S. NAD+-metabolizing ecto-enzymes shape tumor-host interactions: The chronic lymphocytic leukemia model. FEBS Lett. 2011, 585, 1514-1520. [CrossRef] [PubMed]

33. Rao, S.R.; Snaith, A.E.; Marino, D.; Cheng, X.; Lwin, S.T.; Orriss, I.R.; Hamdy, F.C.; Edwards, C.M. Tumour-derived alkaline phosphatase regulates tumour growth, epithelial plasticity and disease-free survival in metastatic prostate cancer. Br. J. Cancer 2017, 116, 227-236. [CrossRef] [PubMed]

34. Bilski, J.; Mazur-Bialy, A.; Wojcik, D.; Zahradnik-Bilska, J.; Brzozowski, B.; Magierowski, M.; Mach, T.; Magierowska, K.; Brzozowski, T. The Role of Intestinal Alkaline Phosphatase in Inflammatory Disorders of Gastrointestinal Tract. Mediat. Inflamm. 2017, 2017, 9074601. [CrossRef] [PubMed]

35. Morandi, F.; Morandi, B.; Horenstein, A.L.; Chillemi, A.; Quarona, V.; Zaccarello, G.; Carrega, P.; Ferlazzo, G.; Mingari, M.C.; Moretta, L.; et al. A non-canonical adenosinergic pathway led by CD38 in human melanoma cells induces suppression of T cell proliferation. Oncotarget 2015, 6, 25602-25618. [CrossRef]

36. Morandi, F.; Horenstein, A.L.; Chillemi, A.; Quarona, V.; Chiesa, S.; Imperatori, A.; Zanellato, S.; Mortara, L.; Gattorno, M.; Pistoia, V.; et al. CD56brightCD16- NK Cells Produce Adenosine through a CD38-Mediated Pathway and Act as Regulatory Cells Inhibiting Autologous CD4+ T Cell Proliferation. J. Immunol. 2015, 195, 965-972. [CrossRef]

37. Stockwell, J.; Jakova, E.; Cayabyab, F.S. Adenosine A1 and A2A Receptors in the Brain: Current Research and Their Role in Neurodegeneration. Molecules 2017, 22, 676. [CrossRef]

38. Ben-Ari Fuchs, S.; Horenstein, A.L.; Chillemi, A.; Quarona, V.; Chiesa, S.; Imperatori, A.; Zanellato, S.; Mortara, L.; Gattorno, M.; Pistoia, V.; et al. GeneAnalytics: An Integrative Gene Set Analysis Tool for Next Generation Sequencing, RNAseq and Microarray Data. Omics 2016, 20, 139-151. [CrossRef] 
39. Fredholm, B.B.; Ap, I.J.; Jacobson, K.A.; Linden, J.; Muller, C.E. International Union of Basic and Clinical Pharmacology. LXXXI. Nomenclature and classification of adenosine receptors-An update. Pharmacol. Rev. 2011, 63, 1-34. [CrossRef]

40. Fredholm, B.B.; Ap, I.J.; Jacobson, K.A.; Klotz, K.N.; Linden, J. International Union of Pharmacology. XXV. Nomenclature and classification of adenosine receptors. Pharmacol. Rev. 2001, 53, 527-552.

41. Gomez, G.; Sitkovsky, M.V. Differential requirement for A2a and A3 adenosine receptors for the protective effect of inosine in vivo. Blood 2003, 102, 4472-4478. [CrossRef] [PubMed]

42. Hasko, G.; Kuhel, D.G.; Nemeth, Z.H.; Mabley, J.G.; Stachlewitz, R.F.; Virag, L.; Lohinai, Z.; Southan, G.J.; Salzman, A.L.; Szabo, C. Inosine inhibits inflammatory cytokine production by a posttranscriptional mechanism and protects against endotoxin-induced shock. J. Immunol. 2000, 164, 1013-1019. [CrossRef] [PubMed]

43. Tilley, S.L.; Wagoner, V.A.; Salvatore, C.A.; Jacobson, M.A.; Koller, B.H. Adenosine and inosine increase cutaneous vasopermeability by activating A3 receptors on mast cells. J. Clin. Investig. 2000, 105, 361-367. [CrossRef] [PubMed]

44. da Rocha Lapa, F.; de Oliveira, A.P.; Accetturi, B.G.; de Oliveira Martins, I.; Domingos, H.V.; de Almeida Cabrini, D.; de Lima, W.T.; Santos, A.R. Anti-inflammatory effects of inosine in allergic lung inflammation in mice: Evidence for the participation of adenosine A2A and A 3 receptors. Purinergic Signal. 2013, 9, 325-336. [CrossRef] [PubMed]

45. Sengmany, K.; Singh, J.; Stewart, G.D.; Conn, P.J.; Christopoulos, A.; Gregory, K.J. Biased allosteric agonism and modulation of metabotropic glutamate receptor 5: Implications for optimizing preclinical neuroscience drug discovery. Neuropharmacology 2017, 115, 60-72. [CrossRef] [PubMed]

46. Welihinda, A.A.; Kaur, M.; Greene, K.; Zhai, Y.; Amento, E.P. The adenosine metabolite inosine is a functional agonist of the adenosine $\mathrm{A}(2 \mathrm{~A})$ receptor with a unique signaling bias. Cell. Signal. 2016, 28, 552-560. [CrossRef] [PubMed]

47. Klaasse, E.C.; Ijzerman, A.P.; de Grip, W.J.; Beukers, M.W. Internalization and desensitization of adenosine receptors. Purinergic Signal. 2008, 4, 21-37. [CrossRef]

48. Mundell, S.; Kelly, E. Adenosine receptor desensitization and trafficking. Biochim. Biophys. Acta 2011, 1808, 1319-1328. [CrossRef]

49. Wootten, D.; Christopoulos, A.; Marti-Solano, M.; Babu, M.M.; Sexton, P.M. Mechanisms of signalling and biased agonism in G protein-coupled receptors. Nat. Rev. Mol. Cell Biol. 2018, 19, 638-653. [CrossRef]

50. Ellisdon, A.M.; Halls, M.L. Compartmentalization of GPCR signalling controls unique cellular responses. Biochem. Soc. Trans. 2016, 44, 562-567. [CrossRef]

51. Lasley, R.D. Adenosine receptors and membrane microdomains. Biochim. Biophys. Acta 2011, 1808, 1284-1289. [CrossRef] [PubMed]

52. Sun, Y.; Huang, P. Adenosine A2B Receptor: From Cell Biology to Human Diseases. Front. Chem. 2016, 4, 37. [CrossRef] [PubMed]

53. Borea, P.A.; Varani, K.; Vincenzi, F.; Baraldi, P.G.; Tabrizi, M.A.; Merighi, S.; Gessi, S. The A3 adenosine receptor: History and perspectives. Pharmacol. Rev. 2015, 67, 74-102. [CrossRef] [PubMed]

54. Panjehpour, M.; Castro, M.; Klotz, K.N. Human breast cancer cell line MDA-MB-231 expresses endogenous A2B adenosine receptors mediating a Ca2+ signal. Br. J. Pharmacol. 2005, 145, 211-218. [CrossRef] [PubMed]

55. Arumugham, V.B.; Baldari, C.T. cAMP: A multifaceted modulator of immune synapse assembly and T cell activation. J. Leukoc. Biol. 2017, 101, 1301-1316. [CrossRef] [PubMed]

56. Brudvik, K.W.; Tasken, K. Modulation of T cell immune functions by the prostaglandin E2-cAMP pathway in chronic inflammatory states. Br. J. Pharmacol. 2012, 166, 411-419. [CrossRef] [PubMed]

57. Ruppelt, A.; Mosenden, R.; Gronholm, M.; Aandahl, E.M.; Tobin, D.; Carlson, C.R.; Abrahamsen, H.; Herberg, F.W.; Carpen, O.; Tasken, K. Inhibition of T cell activation by cyclic adenosine $5^{\prime}$-monophosphate requires lipid raft targeting of protein kinase A type I by the A-kinase anchoring protein ezrin. J. Immunol. 2007, 179, 5159-5168. [CrossRef] [PubMed]

58. Raskovalova, T.; Lokshin, A.; Huang, X.; Jackson, E.K.; Gorelik, E. Adenosine-mediated inhibition of cytotoxic activity and cytokine production by IL-2/NKp46-activated NK cells: Involvement of protein kinase A isozyme I (PKA I). Immunol. Res. 2006, 36, 91-99. [CrossRef] 
59. Raskovalova, T.; Lokshin, A.; Huang, X.; Su, Y.; Mandic, M.; Zarour, H.M.; Jackson, E.K.; Gorelik, E. Inhibition of cytokine production and cytotoxic activity of human antimelanoma specific CD8+ and CD4+ T lymphocytes by adenosine-protein kinase A type I signaling. Cancer Res. 2007, 67, 5949-5956. [CrossRef]

60. Vang, A.G.; Housley, W.; Dong, H.; Basole, C.; Ben-Sasson, S.Z.; Kream, B.E.; Epstein, P.M.; Clark, R.B.; Brocke, S. Regulatory T-cells and cAMP suppress effector T-cells independently of PKA-CREM/ICER: A potential role for Epac. Biochem. J. 2013, 456, 463-473. [CrossRef]

61. Almahariq, M.; Mei, F.C.; Wang, H.; Cao, A.T.; Yao, S.; Soong, L.; Sun, J.; Cong, Y.; Chen, J.; Cheng, X. Exchange protein directly activated by cAMP modulates regulatory T-cell-mediated immunosuppression. Biochem. J. 2015, 465, 295-303. [CrossRef] [PubMed]

62. Stork, P.J.; Dillon, T.J. Multiple roles of Rap1 in hematopoietic cells: Complementary versus antagonistic functions. Blood 2005, 106, 2952-2961. [CrossRef] [PubMed]

63. Hara, S.; Nakaseko, C.; Yamasaki, S.; Hattori, M.; Bos, J.L.; Saito, Y.; Minato, N.; Saito, T. Involvement of Rap-1 activation and early termination of immune synapse in CTLA-4-mediated negative signal. Hematology 2009, 14, 150-158. [CrossRef] [PubMed]

64. Cadieux, J.S.; Leclerc, P.; St-Onge, M.; Dussault, A.A.; Laflamme, C.; Picard, S.; Ledent, C.; Borgeat, P.; Pouliot, M. Potentiation of neutrophil cyclooxygenase-2 by adenosine: An early anti-inflammatory signal. J. Cell Sci. 2005, 118 Pt 7, 1437-1447. [CrossRef]

65. Ernens, I.; Rouy, D.; Velot, E.; Devaux, Y.; Wagner, D.R. Adenosine inhibits matrix metalloproteinase-9 secretion by neutrophils: Implication of A2a receptor and cAMP/PKA/Ca ${ }^{2+}$ pathway. Circ. Res. 2006, 99, 590-597. [CrossRef]

66. Hwang, T.L.; Yeh, S.H.; Leu, Y.L.; Chern, C.Y.; Hsu, H.C. Inhibition of superoxide anion and elastase release in human neutrophils by $3^{\prime}$-isopropoxychalcone via a cAMP-dependent pathway. Br. J. Pharmacol. 2006, 148, 78-87. [CrossRef]

67. Link, A.A.; Kino, T.; Worth, J.A.; McGuire, J.L.; Crane, M.L.; Chrousos, G.P.; Wilder, R.L.; Elenkov, I.J. Ligand-activation of the adenosine A2a receptors inhibits IL-12 production by human monocytes. J. Immunol. 2000, 164, 436-442. [CrossRef]

68. Aronoff, D.M.; Canetti, C.; Serezani, C.H.; Luo, M.; Peters-Golden, M. Cutting edge: Macrophage inhibition by cyclic AMP (cAMP): Differential roles of protein kinase A and exchange protein directly activated by cAMP-1. J. Immunol. 2005, 174, 595-599. [CrossRef]

69. Minguet, S.; Huber, M.; Rosenkranz, L.; Schamel, W.W.; Reth, M.; Brummer, T. Adenosine and cAMP are potent inhibitors of the NF-кB pathway downstream of immunoreceptors. Eur. J. Immunol. 2005, 35, 31-41. [CrossRef]

70. Takahashi, H.K.; Iwagaki, H.; Hamano, R.; Kanke, T.; Liu, K.; Sadamori, H.; Yagi, T.; Yoshino, T.; Sendo, T.; Tanaka, N.; et al. Effect of adenosine receptor subtypes stimulation on mixed lymphocyte reaction. Eur. J. Pharmacol. 2007, 564, 204-210. [CrossRef]

71. Gessi, S.; Varani, K.; Merighi, S.; Morelli, A.; Ferrari, D.; Leung, E.; Baraldi, P.G.; Spalluto, G.; Borea, P.A. Pharmacological and biochemical characterization of A3 adenosine receptors in Jurkat T cells. Br. J. Pharmacol. 2001, 134, 116-126. [CrossRef] [PubMed]

72. Gessi, S.; Varani, K.; Merighi, S.; Cattabriga, E.; Avitabile, A.; Gavioli, R.; Fortini, C.; Leung, E.; Lennan, S.M.; Borea, P.A. Expression of A3 Adenosine Receptors in Human Lymphocytes: Up-Regulation in T Cell Activation. Mol. Pharmacol. 2004, 65, 711-719. [CrossRef] [PubMed]

73. Gessi, S.; Sacchetto, V.; Fogli, E.; Merighi, S.; Varani, K.; Baraldi, P.G.; Tabrizi, M.A.; Leung, E.; Maclennan, S.; Borea, P.A. Modulation of metalloproteinase-9 in U87MG glioblastoma cells by A3 adenosine receptors. Biochem. Pharmacol. 2010, 79, 1483-1495. [CrossRef] [PubMed]

74. Zhao, R.; Wang, S.; Huang, Z.; Zhang, L.; Yang, X.; Bai, X.; Zhou, D.; Qin, Z.; Du, G. Lipopolysaccharide-induced serotonin transporter up-regulation involves PKG-I and p38MAPK activation partially through A3 adenosine receptor. Biosci. Trends 2015, 9, 367-376. [CrossRef] [PubMed]

75. Zheng, L.; Chen, J.; Huang, Y.; Wang, Y.; Yang, H.; Zhang, Y.; Xie, S. Evidence for A1 and A3 receptors mediating adenosine-induced intracellular calcium release in the dorsal root ganglion neurons by using confocal microscopy imaging. Lasers Med. Sci. 2014, 29, 1209-1215. [CrossRef] [PubMed] 
76. Koszalka, P.; Golunska, M.; Urban, A.; Stasilojc, G.; Stanislawowski, M.; Majewski, M.; Skladanowski, A.C.; Bigda, J. Specific Activation of A3, A2A and A1 Adenosine Receptors in CD73-Knockout Mice Affects B16F10 Melanoma Growth, Neovascularization, Angiogenesis and Macrophage Infiltration. PLoS ONE 2016, 11, e0151420. [CrossRef] [PubMed]

77. Ethier, M.F.; Madison, J.M. Adenosine A1 receptors mediate mobilization of calcium in human bronchial smooth muscle cells. Am. J. Respir. Cell Mol. Biol. 2006, 35, 496-502. [CrossRef] [PubMed]

78. Forte, G.; Sorrentino, R.; Montinaro, A.; Pinto, A.; Morello, S. Cl-IB-MECA enhances TNF- $\alpha$ release in peritoneal macrophages stimulated with LPS. Cytokine 2011, 54, 161-166. [CrossRef]

79. Mozzicato, S.; Joshi, B.V.; Jacobson, K.A.; Liang, B.T. Role of direct RhoA-phospholipase D1 interaction in mediating adenosine-induced protection from cardiac ischemia. FASEB J. 2004, 18, 406-408. [CrossRef]

80. Kim, T.H.; Kim, Y.K.; Woo, J.S. The adenosine A3 receptor agonist Cl-IB-MECA induces cell death through $\mathrm{Ca}^{2+} /$ ROS-dependent down regulation of ERK and Akt in A172 human glioma cells. Neurochem. Res. 2012, 37, 2667-2677. [CrossRef]

81. Merighi, S.; Varani, K.; Gessi, S.; Cattabriga, E.; Iannotta, V.; Ulouglu, C.; Leung, E.; Borea, P.A. Pharmacological and biochemical characterization of adenosine receptors in the human malignant melanoma A375 cell line. Br. J. Pharmacol. 2001, 134, 1215-1226. [CrossRef] [PubMed]

82. Etique, N.; Grillier-Vuissoz, I.; Lecomte, J.; Flament, S. Crosstalk between adenosine receptor (A2A isoform) and ER $\alpha$ mediates ethanol action in MCF-7 breast cancer cells. Oncol. Rep. 2009, 21, 977-981. [PubMed]

83. Mediavilla-Varela, M.; Luddy, K.; Noyes, D.; Khalil, F.K.; Neuger, A.M.; Soliman, H.; Antonia, S.J. Antagonism of adenosine A2A receptor expressed by lung adenocarcinoma tumor cells and cancer associated fibroblasts inhibits their growth. Cancer Biol. Ther. 2013, 14, 860-868. [CrossRef] [PubMed]

84. Kasama, H.; Sakamoto, Y.; Kasamatsu, A.; Okamoto, A.; Koyama, T.; Minakawa, Y.; Ogawara, K.; Yokoe, H.; Shiiba, M.; Tanzawa, H.; et al. Adenosine A2b receptor promotes progression of human oral cancer. BMC Cancer 2015, 15, 563. [CrossRef] [PubMed]

85. Vecchio, E.A.; Tan, C.Y.; Gregory, K.J.; Christopoulos, A.; White, P.J.; May, L.T. Ligand-Independent Adenosine A2B Receptor Constitutive Activity as a Promoter of Prostate Cancer Cell Proliferation. J. Pharmacol. Exp. Ther. 2016, 357, 36-44. [CrossRef] [PubMed]

86. Merighi, S.; Benini, A.; Mirandola, P.; Gessi, S.; Varani, K.; Leung, E.; MacLennan, S.; Baraldi, P.G.; Borea, P.A. A3 adenosine receptors modulate hypoxia-inducible factor- $1 \alpha$ expression in human A375 melanoma cells. Neoplasia 2005, 7, 894-903. [CrossRef] [PubMed]

87. Suh, B.C.; Kim, T.D.; Lee, J.U.; Seong, J.K.; Kim, K.T. Pharmacological characterization of adenosine receptors in PGT- $\beta$ mouse pineal gland tumour cells. Br. J. Pharmacol. 2001, 134, 132-142. [CrossRef] [PubMed]

88. Kazemi, M.H.; Raoofi Mohseni, S.; Hojjat-Farsangi, M.; Anvari, E.; Ghalamfarsa, G.; Mohammadi, H.; Jadidi-Niaragh, F. Adenosine and adenosine receptors in the immunopathogenesis and treatment of cancer. J. Cell. Physiol. 2018, 233, 2032-2057. [CrossRef]

89. Madi, L.; Ochaion, A.; Rath-Wolfson, L.; Bar-Yehuda, S.; Erlanger, A.; Ohana, G.; Harish, A.; Merimski, O.; Barer, F.; Fishman, P. The A3 adenosine receptor is highly expressed in tumor versus normal cells: Potential target for tumor growth inhibition. Clin. Cancer Res. 2004, 10, 4472-4479. [CrossRef]

90. Gessi, S.; Cattabriga, E.; Avitabile, A.; Gafa, R.; Lanza, G.; Cavazzini, L.; Bianchi, N.; Gambari, R.; Feo, C.; Liboni, A.; et al. Elevated expression of A3 adenosine receptors in human colorectal cancer is reflected in peripheral blood cells. Clin. Cancer Res. 2004, 10, 5895-5901. [CrossRef]

91. Polycarpou, E.; Meira, L.B.; Carrington, S.; Tyrrell, E.; Modjtahedi, H.; Carew, M.A. Resveratrol 3-O-D-glucuronide and resveratrol 4'-O-D-glucuronide inhibit colon cancer cell growth: Evidence for a role of A3 adenosine receptors, cyclin D1 depletion, and G1 cell cycle arrest. Mol. Nutr. Food Res. 2013, 57, 1708-1717. [CrossRef] [PubMed]

92. Bar-Yehuda, S.; Barer, F.; Volfsson, L.; Fishman, P. Resistance of muscle to tumor metastases: A role for a3 adenosine receptor agonists. Neoplasia 2001, 3, 125-131. [CrossRef] [PubMed]

93. Fishman, P.; Bar-Yehuda, S.; Ohana, G.; Pathak, S.; Wasserman, L.; Barer, F.; Multani, A.S. Adenosine acts as an inhibitor of lymphoma cell growth: A major role for the A3 adenosine receptor. Eur. J. Cancer 2000, 36, 1452-1458. [CrossRef]

94. Fishman, P.; Bar-Yehuda, S.; Madi, L.; Cohn, I. A3 adenosine receptor as a target for cancer therapy. Anticancer Drugs 2002, 13, 437-443. [CrossRef] [PubMed] 
95. Aghaei, M.; Panjehpour, M.; Karami-Tehrani, F.; Salami, S. Molecular mechanisms of A3 adenosine receptor-induced G1 cell cycle arrest and apoptosis in androgen-dependent and independent prostate cancer cell lines: Involvement of intrinsic pathway. J. Cancer Res. Clin. Oncol. 2011, 137, 1511-1523. [CrossRef] [PubMed]

96. Fishman, P.; Panjehpour, M.; Karami-Tehrani, F.; Salami, S. Targeting the A3 adenosine receptor for cancer therapy: Inhibition of prostate carcinoma cell growth by A3AR agonist. Anti Cancer Res. 2003, 23, 2077-2083.

97. Gessi, S.; Merighi, S.; Varani, K.; Cattabriga, E.; Benini, A.; Mirandola, P.; Leung, E.; Mac Lennan, S.; Feo, C.; Baraldi, S.; et al. Adenosine receptors in colon carcinoma tissues and colon tumoral cell lines: Focus on the A3 adenosine subtype. J. Cell. Physiol. 2007, 211, 826-836. [CrossRef]

98. Merighi, S.; Merighi, S.; Varani, K.; Cattabriga, E.; Benini, A.; Mirandola, P.; Leung, E.; Mac Lennan, S.; Feo, C.; Baraldi, S.; et al. Caffeine inhibits adenosine-induced accumulation of hypoxia-inducible factor- $1 \alpha$, vascular endothelial growth factor, and interleukin-8 expression in hypoxic human colon cancer cells. Mol. Pharmacol. 2007, 72, 395-406. [CrossRef]

99. Bar-Yehuda, S.; Stemmer, S.M.; Madi, L.; Castel, D.; Ochaion, A.; Cohen, S.; Barer, F.; Zabutti, A.; Perez-Liz, G.; Del Valle, L.; et al. The A3 adenosine receptor agonist CF102 induces apoptosis of hepatocellular carcinoma via de-regulation of the Wnt and NF-kB signal transduction pathways. Int. J. Oncol. 2008, 33, 287-295.

100. Soares, A.S.; Costa, V.M.; Diniz, C.; Fresco, P. Inosine strongly enhances proliferation of human C32 melanoma cells through PLC-PKC-MEK1/2-ERK1/2 and PI3K pathways. Basic Clin. Pharmacol. Toxicol. 2015, 116, 25-36. [CrossRef]

101. Modis, K.; Gero, D.; Nagy, N.; Szoleczky, P.; Toth, Z.D.; Szabo, C. Cytoprotective effects of adenosine and inosine in an in vitro model of acute tubular necrosis. Br. J. Pharmacol. 2009, 158, 1565-1578. [CrossRef] [PubMed]

102. Ren, Z.-H.; Lin, C.-Z.; Cao, W.; Yang, R.; Lu, W.; Liu, Z.-Q.; Chen, Y.-M.; Yang, X.; Tian, Z.; Wang, L.-Z.; et al. CD73 is associated with poor prognosis in HNSCC. Oncotarget 2016, 7, 61690-61702. [CrossRef] [PubMed]

103. Soares, A.S.; Costa, V.M.; Diniz, C.; Fresco, P. The combination of Cl-IB-MECA with paclitaxel: A new anti-metastatic therapeutic strategy for melanoma. Cancer Chemother. Pharmacol. 2014, 74, 847-860. [CrossRef] [PubMed]

104. Sakowicz-Burkiewicz, M.; Kocbuch, K.; Grden, M.; Maciejewska, I.; Szutowicz, A.; Pawelczyk, T. Impact of adenosine receptors on immunoglobulin production by human peripheral blood B lymphocytes. J. Physiol. Pharmacol. 2012, 63, 661-668. [PubMed]

105. Sepulveda, C.; Palomo, I.; Fuentes, E. Role of adenosine A2b receptor overexpression in tumor progression. Life Sci. 2016, 166, 92-99. [CrossRef] [PubMed]

106. Wei, Q.; Costanzi, S.; Balasubramanian, R.; Gao, Z.G.; Jacobson, K.A. A2B adenosine receptor blockade inhibits growth of prostate cancer cells. Purinergic Signal. 2013, 9, 271-280. [CrossRef] [PubMed]

107. Kalhan, A.; Gharibi, B.; Vazquez, M.; Jasani, B.; Neal, J.; Kidd, M.; Modlin, I.M.; Pfragner, R.; Rees, D.A.; Ham, J. Adenosine A2A and A2B receptor expression in neuroendocrine tumours: Potential targets for therapy. Purinergic Signal. 2012, 8, 265-274. [CrossRef]

108. Zhou, Y.; Chu, X.; Deng, F.; Tong, L.; Tong, G.; Yi, Y.; Liu, J.; Tang, J.; Tang, Y.; Xia, Y.; et al. The adenosine $\mathrm{A} 2 \mathrm{~b}$ receptor promotes tumor progression of bladder urothelial carcinoma by enhancing MAPK signaling pathway. Oncotarget 2017, 8, 48755-48768. [CrossRef]

109. Mittal, D.; Sinha, D.; Barkauskas, D.; Young, A.; Kalimutho, M.; Stannard, K.; Caramia, F.; Haibe-Kains, B.; Stagg, J.; Khanna, K.K.; et al. Adenosine 2B Receptor Expression on Cancer Cells Promotes Metastasis. Cancer Res. 2016, 76, 4372-4382. [CrossRef]

110. Beavis, P.A.; Divisekera, U.; Paget, C.; Chow, M.T.; John, L.B.; Devaud, C.; Dwyer, K.; Stagg, J.; Smyth, M.J.; Darcy, P.K. Blockade of A2A receptors potently suppresses the metastasis of CD73+ tumors. Proc. Natl. Acad. Sci. USA 2013, 110, 14711-14716. [CrossRef]

111. Fernandez-Gallardo, M.; Gonzalez-Ramirez, R.; Sandoval, A.; Felix, R.; Monjaraz, E. Adenosine Stimulate Proliferation and Migration in Triple Negative Breast Cancer Cells. PLoS ONE 2016, 11, e0167445. [CrossRef] [PubMed]

112. Desmet, C.J.; Gallenne, T.; Prieur, A.; Reyal, F.; Visser, N.L.; Wittner, B.S.; Smit, M.A.; Geiger, T.R.; Laoukili, J.; Iskit, S.; et al. Identification of a pharmacologically tractable Fra-1/ADORA2B axis promoting breast cancer metastasis. Proc. Natl. Acad. Sci. USA 2013, 110, 5139-5144. [CrossRef] [PubMed] 
113. Giacomelli, C.; Daniele, S.; Romei, C.; Tavanti, L.; Neri, T.; Piano, I.; Celi, A.; Martini, C.; Trincavelli, M.L. The A2B Adenosine Receptor Modulates the Epithelial- Mesenchymal Transition through the Balance of cAMP/PKA and MAPK/ERK Pathway Activation in Human Epithelial Lung Cells. Front. Pharmacol. 2018, 9, 54. [CrossRef] [PubMed]

114. Feoktistov, I.; Goldstein, A.E.; Ryzhov, S.; Zeng, D.; Belardinelli, L.; Voyno-Yasenetskaya, T.; Biaggioni, I. Differential expression of adenosine receptors in human endothelial cells: Role of A2B receptors in angiogenic factor regulation. Circ. Res. 2002, 90, 531-538. [CrossRef] [PubMed]

115. Sorrentino, C.; Miele, L.; Porta, A.; Pinto, A.; Morello, S. Myeloid-derived suppressor cells contribute to A2B adenosine receptor-induced VEGF production and angiogenesis in a mouse melanoma model. Oncotarget 2015, 6, 27478-27489. [CrossRef] [PubMed]

116. Ma, S.R.; Deng, W.W.; Liu, J.F.; Mao, L.; Yu, G.T.; Bu, L.L.; Kulkarni, A.B.; Zhang, W.F.; Sun, Z.J. Blockade of adenosine A2A receptor enhances CD8+ T cells response and decreases regulatory T cells in head and neck squamous cell carcinoma. Mol. Cancer 2017, 16, 99. [CrossRef] [PubMed]

117. Merighi, S.; Mirandola, P.; Milani, D.; Varani, K.; Gessi, S.; Klotz, K.N.; Leung, E.; Baraldi, P.G.; Borea, P.A. Adenosine receptors as mediators of both cell proliferation and cell death of cultured human melanoma cells. J. Investig. Dermatol. 2002, 119, 923-933. [CrossRef]

118. Gessi, S.; Bencivenni, S.; Battistello, E.; Vincenzi, F.; Colotta, V.; Catarzi, D.; Varano, F.; Merighi, S.; Borea, P.A.; Varani, K. Inhibition of A2A Adenosine Receptor Signaling in Cancer Cells Proliferation by the Novel Antagonist TP455. Front. Pharmacol. 2017, 8, 888. [CrossRef]

119. Zhou, Y.; Tong, L.; Chu, X.; Deng, F.; Tang, J.; Tang, Y.; Dai, Y. The Adenosine A1 Receptor Antagonist DPCPX Inhibits Tumor Progression via the ERK/JNK Pathway in Renal Cell Carcinoma. Cell. Physiol. Biochem. 2017, 43, 733-742. [CrossRef]

120. Lukashev, D.E.; Smith, P.T.; Caldwell, C.C.; Ohta, A.; Apasov, S.G.; Sitkovsky, M.V. Analysis of A2a receptor-deficient mice reveals no significant compensatory increases in the expression of A2b, A1, and A3 adenosine receptors in lymphoid organs. Biochem. Pharmacol. 2003, 65, 2081-2090. [CrossRef]

121. Mirabet, M.; Herrera, C.; Cordero, O.J.; Mallol, J.; Lluis, C.; Franco, R. Expression of A2B adenosine receptors in human lymphocytes: Their role in T cell activation. J. Cell Sci. 1999, 112 Pt 4, 491-502.

122. Zarek, P.E.; Huang, C.T.; Lutz, E.R.; Kowalski, J.; Horton, M.R.; Linden, J.; Drake, C.G.; Powell, J.D. A2A receptor signaling promotes peripheral tolerance by inducing T-cell anergy and the generation of adaptive regulatory T cells. Blood 2008, 111, 251-259. [CrossRef] [PubMed]

123. Erdmann, A.A.; Gao, Z.G.; Jung, U.; Foley, J.; Borenstein, T.; Jacobson, K.A.; Fowler, D.H. Activation of Th1 and Tc1 cell adenosine A2A receptors directly inhibits IL-2 secretion in vitro and IL-2-driven expansion in vivo. Blood 2005, 105, 4707-4714. [CrossRef] [PubMed]

124. Csoka, B.; Himer, L.; Selmeczy, Z.; Vizi, E.S.; Pacher, P.; Ledent, C.; Deitch, E.A.; Spolarics, Z.; Nemeth, Z.H.; Hasko, G. Adenosine A2A receptor activation inhibits T helper 1 and T helper 2 cell development and effector function. FASEB J. 2008, 22, 3491-3499. [CrossRef] [PubMed]

125. Jin, D.; Fan, J.; Wang, L.; Thompson, L.F.; Liu, A.; Daniel, B.J.; Shin, T.; Curiel, T.J.; Zhang, B. CD73 on tumor cells impairs antitumor T-cell responses: A novel mechanism of tumor-induced immune suppression. Cancer Res. 2010, 70, 2245-2255. [CrossRef] [PubMed]

126. Deaglio, S.; Dwyer, K.M.; Gao, W.; Friedman, D.; Usheva, A.; Erat, A.; Chen, J.F.; Enjyoji, K.; Linden, J.; Oukka, M.; et al. Adenosine generation catalyzed by CD39 and CD73 expressed on regulatory T cells mediates immune suppression. J. Exp. Med. 2007, 204, 1257-1265. [CrossRef] [PubMed]

127. Ohta, A.; Ohta, A.; Madasu, M.; Kini, R.; Subramanian, M.; Goel, N.; Sitkovsky, M. A2A adenosine receptor may allow expansion of $\mathrm{T}$ cells lacking effector functions in extracellular adenosine-rich microenvironments. J. Immunol. 2009, 183, 5487-5493. [CrossRef]

128. Beavis, P.A.; Henderson, M.A.; Giuffrida, L.; Mills, J.K.; Sek, K.; Cross, R.S.; Davenport, A.J.; John, L.B.; Mardiana, S.; Slaney, C.Y.; et al. Targeting the adenosine 2A receptor enhances chimeric antigen receptor T cell efficacy. J. Clin. Investig. 2017, 127, 929-941. [CrossRef]

129. Ohta, A.; Madasu, M.; Subramanian, M.; Kini, R.; Jones, G.; Chouker, A.; Ohta, A.; Sitkovsky, M. Hypoxia-induced and A2A adenosine receptor-independent T-cell suppression is short lived and easily reversible. Int. Immunol. 2014, 26, 83-91. [CrossRef]

130. Lappas, C.M.; Rieger, J.M.; Linden, J. A2A adenosine receptor induction inhibits IFN-gamma production in murine CD4+ T cells. J. Immunol. 2005, 174, 1073-1080. [CrossRef] 
131. Beavis, P.A.; Milenkovski, N.; Henderson, M.A.; John, L.B.; Allard, B.; Loi, S.; Kershaw, M.H.; Stagg, J.; Darcy, P.K. Adenosine Receptor 2A Blockade Increases the Efficacy of Anti-PD-1 through Enhanced Antitumor T-cell Responses. Cancer Immunol. Res. 2015, 3, 506-517. [CrossRef] [PubMed]

132. Romio, M.; Reinbeck, B.; Bongardt, S.; Huls, S.; Burghoff, S.; Schrader, J. Extracellular purine metabolism and signaling of CD73-derived adenosine in murine Treg and Teff cells. Am. J. Physiol. Cell Physiol. 2011, 301, C530-C539. [CrossRef] [PubMed]

133. Naganuma, M.; Wiznerowicz, E.B.; Lappas, C.M.; Linden, J.; Worthington, M.T.; Ernst, P.B. Cutting edge: Critical role for A2A adenosine receptors in the T cell-mediated regulation of colitis. J. Immunol. 2006, 177, 2765-2769. [CrossRef] [PubMed]

134. Bruzzese, L.; Fromonot, J.; By, Y.; Durand-Gorde, J.M.; Condo, J.; Kipson, N.; Guieu, R.; Fenouillet, E.; Ruf, J. NF- $\mathrm{B}$ B enhances hypoxia-driven T-cell immunosuppression via upregulation of adenosine $\mathrm{A}(2 \mathrm{~A})$ receptors. Cell Signal. 2014, 26, 1060-1067. [CrossRef] [PubMed]

135. By, Y.; Jacquin, L.; Franceschi, F.; Durand-Gorde, J.-M.; Condo, J.; Michelet, P.; Guieu, R.; Ruf, J. Fall in oxygen tension of culture medium stimulates the adenosinergic signalling of a human T cell line. Purinergic Signal. 2012, 8, 661-667. [CrossRef] [PubMed]

136. Mills, J.H.; Kim, D.G.; Krenz, A.; Chen, J.F.; Bynoe, M.S. A2A adenosine receptor signaling in lymphocytes and the central nervous system regulates inflammation during experimental autoimmune encephalomyelitis. J. Immunol. 2012, 188, 5713-5722. [CrossRef] [PubMed]

137. Thiel, M.; Chouker, A.; Ohta, A.; Jackson, E.; Caldwell, C.; Smith, P.; Lukashev, D.; Bittmann, I.; Sitkovsky, M.V. Oxygenation inhibits the physiological tissue-protecting mechanism and thereby exacerbates acute inflammatory lung injury. PLoS Biol. 2005, 3, e174. [CrossRef]

138. Huang, S.; Apasov, S.; Koshiba, M.; Sitkovsky, M. Role of A2a extracellular adenosine receptor-mediated signaling in adenosine-mediated inhibition of T-cell activation and expansion. Blood 1997, 90, 1600-1610.

139. Mosenden, R.; Tasken, K. Cyclic AMP-mediated immune regulation-overview of mechanisms of action in T cells. Cell Signal. 2011, 23, 1009-1016. [CrossRef]

140. Armstrong, J.M.; Chen, J.F.; Schwarzschild, M.A.; Apasov, S.; Smith, P.T.; Caldwell, C.; Chen, P.; Figler, H.; Sullivan, G.; Fink, S.; et al. Gene dose effect reveals no Gs-coupled A2A adenosine receptor reserve in murine T-lymphocytes: Studies of cells from A2A-receptor-gene-deficient mice. Biochem. J. 2001, 354 Pt 1, 123-130. [CrossRef]

141. Linnemann, C.; Schildberg, F.A.; Schurich, A.; Diehl, L.; Hegenbarth, S.I.; Endl, E.; Lacher, S.; Muller, C.E.; Frey, J.; Simeoni, L.; et al. Adenosine regulates CD8 T-cell priming by inhibition of membrane-proximal T-cell receptor signalling. Immunology 2009, 128 (Suppl. 1), e728-e737. [CrossRef] [PubMed]

142. Cekic, C.; Sag, D.; Day, Y.J.; Linden, J. Extracellular adenosine regulates naive T cell development and peripheral maintenance. J. Exp. Med. 2013, 210, 2693-2706. [CrossRef] [PubMed]

143. Zhang, H.; Conrad, D.M.; Butler, J.J.; Zhao, C.; Blay, J.; Hoskin, D.W. Adenosine acts through A2 receptors to inhibit IL-2-induced tyrosine phosphorylation of STAT5 in T lymphocytes: Role of cyclic adenosine 3',5'-monophosphate and phosphatases. J. Immunol. 2004, 173, 932-944. [CrossRef] [PubMed]

144. Jenabian, M.A.; Seddiki, N.; Yatim, A.; Carriere, M.; Hulin, A.; Younas, M.; Ghadimi, E.; Kok, A.; Routy, J.P.; Tremblay, A.; et al. Regulatory $\mathrm{T}$ cells negatively affect IL-2 production of effector $\mathrm{T}$ cells through CD39/adenosine pathway in HIV infection. PLoS Pathog. 2013, 9, e1003319. [CrossRef] [PubMed]

145. Hoskin, D.W.; Butler, J.J.; Drapeau, D.; Haeryfar, S.M.; Blay, J. Adenosine acts through an A3 receptor to prevent the induction of murine anti-CD3-activated killer T cells. Int. J. Cancer 2002, 99, 386-395. [CrossRef] [PubMed]

146. Montinaro, A.; Forte, G.; Sorrentino, R.; Luciano, A.; Palma, G.; Arra, C.; Adcock, I.M.; Pinto, A.; Morello, S. Adoptive immunotherapy with Cl-IB-MECA-treated CD8+ T cells reduces melanoma growth in mice. PLoS ONE 2012, 7, e45401. [CrossRef]

147. Morello, S.; Sorrentino, R.; Montinaro, A.; Luciano, A.; Maiolino, P.; Ngkelo, A.; Arra, C.; Adcock, I.M.; Pinto, A. NK1.1 cells and CD8 T cells mediate the antitumor activity of Cl-IB-MECA in a mouse melanoma model. Neoplasia 2011, 13, 365-373. [CrossRef]

148. Yaar, R.; Cataldo, L.M.; Tzatsos, A.; Francis, C.E.; Zhao, Z.; Ravid, K. Regulation of the A3 adenosine receptor gene in vascular smooth muscle cells: Role of a cAMP and GATA element. Mol. Pharmacol 2002, 62, 1167-1176. [CrossRef] 
149. Ohta, A.; Kini, R.; Ohta, A.; Subramanian, M.; Madasu, M.; Sitkovsky, M. The development and immunosuppressive functions of $\mathrm{CD} 4(+) \mathrm{CD} 25(+)$ FoxP3(+) regulatory T cells are under influence of the adenosine-A2A adenosine receptor pathway. Front. Immunol. 2012, 3, 190. [CrossRef]

150. Sitkovsky, M.; Lukashev, D.; Deaglio, S.; Dwyer, K.; Robson, S.C.; Ohta, A. Adenosine A2A receptor antagonists: Blockade of adenosinergic effects and T regulatory cells. Br. J. Pharmacol. 2008, 153 (Suppl. 1), S457-S464. [CrossRef]

151. Kinsey, G.R.; Huang, L.; Jaworska, K.; Khutsishvili, K.; Becker, D.A.; Ye, H.; Lobo, P.I.; Okusa, M.D. Autocrine adenosine signaling promotes regulatory T cell-mediated renal protection. J. Am. Soc. Nephrol. 2012, 23, 1528-1537. [CrossRef] [PubMed]

152. Chimote, A.A.; Balajthy, A.; Arnold, M.J.; Newton, H.S.; Hajdu, P.; Qualtieri, J.; Wise-Draper, T.; Conforti, L. A defect in KCa3.1 channel activity limits the ability of CD8+ T cells from cancer patients to infiltrate an adenosine-rich microenvironment. Sci. Signal. 2018, 11, 1616. [CrossRef] [PubMed]

153. Cekic, C.; Linden, J. Adenosine A2A receptors intrinsically regulate CD8+ $\mathrm{T}$ cells in the tumor microenvironment. Cancer Res. 2014, 74, 7239-7249. [CrossRef] [PubMed]

154. Abbott, R.K.; Silva, M.; Labuda, J.; Thayer, M.; Cain, D.W.; Philbrook, P.; Sethumadhavan, S.; Hatfield, S.; Ohta, A.; Sitkovsky, M. The GS Protein-coupled A2a Adenosine Receptor Controls T Cell Help in the Germinal Center. J. Biol. Chem. 2017, 292, 1211-1217. [CrossRef] [PubMed]

155. Serra, S.; Vaisitti, T.; Audrito, V.; Bologna, C.; Buonincontri, R.; Chen, S.S.; Arruga, F.; Brusa, D.; Coscia, M.; Jaksic, O; et al. Adenosine signaling mediates hypoxic responses in the chronic lymphocytic leukemia microenvironment. Blood Adv. 2016, 1, 47-61. [CrossRef] [PubMed]

156. Sun, J.; Zhang, Y.; Yang, M.; Zhang, Y.; Xie, Q.; Li, Z.; Dong, Z.; Yang, Y.; Deng, B.; Feng, A.; et al. Hypoxia induces T-cell apoptosis by inhibiting chemokine $\mathrm{C}$ receptor 7 expression: The role of adenosine receptor $\mathrm{A} 2$. Cell. Mol. Immunol. 2010, 7, 77-82. [CrossRef] [PubMed]

157. Himer, L.; Csoka, B.; Selmeczy, Z.; Koscso, B.; Pocza, T.; Pacher, P.; Nemeth, Z.H.; Deitch, E.A.; Vizi, E.S.; Cronstein, B.N.; et al. Adenosine A2A receptor activation protects CD4+ T lymphocytes against activation-induced cell death. FASEB J. 2010, 24, 2631-2640. [CrossRef]

158. Duhen, T.; Duhen, R.; Montler, R.; Moses, J.; Moudgil, T.; de Miranda, N.F.; Goodall, C.P.; Blair, T.C.; Fox, B.A.; McDermott, J.E.; et al. Co-expression of CD39 and CD103 identifies tumor-reactive CD8 T cells in human solid tumors. Nat. Commun. 2018, 9, 2724. [CrossRef]

159. Philip, M.; Fairchild, L.; Sun, L.; Horste, E.L.; Camara, S.; Shakiba, M.; Scott, A.C.; Viale, A.; Lauer, P.; Merghoub, T.; et al. Chromatin states define tumor-specific T cell dysfunction and reprogramming. Nature 2017, 545, 452-456. [CrossRef]

160. Lappas, C.M.; Day, Y.J.; Marshall, M.A.; Engelhard, V.H.; Linden, J. Adenosine A2A receptor activation reduces hepatic ischemia reperfusion injury by inhibiting CD1d-dependent NKT cell activation. J. Exp. Med. 2006, 203, 2639-2648. [CrossRef]

161. Mittal, D.; Young, A.; Stannard, K.; Yong, M.; Teng, M.W.; Allard, B.; Stagg, J.; Smyth, M.J. Antimetastatic effects of blocking PD-1 and the adenosine A2A receptor. Cancer Res. 2014, 74, 3652-3658. [CrossRef] [PubMed]

162. Young, A.; Ngiow, S.F.; Gao, Y.; Patch, A.M.; Barkauskas, D.S.; Messaoudene, M.; Lin, G.; Coudert, J.D.; Stannard, K.A.; Zitvogel, L.; et al. A2AR Adenosine Signaling Suppresses Natural Killer Cell Maturation in the Tumor Microenvironment. Cancer Res. 2018, 78, 1003-1016. [CrossRef] [PubMed]

163. Raskovalova, T.; Huang, X.; Sitkovsky, M.; Zacharia, L.C.; Jackson, E.K.; Gorelik, E. Gs protein-coupled adenosine receptor signaling and lytic function of activated NK cells. J. Immunol. 2005, 175, 4383-4391. [CrossRef] [PubMed]

164. Wallace, K.L.; Linden, J. Adenosine A2A receptors induced on iNKT and NK cells reduce pulmonary inflammation and injury in mice with sickle cell disease. Blood 2010, 116, 5010-5020. [CrossRef] [PubMed]

165. Lokshin, A.; Raskovalova, T.; Huang, X.; Zacharia, L.C.; Jackson, E.K.; Gorelik, E. Adenosine-mediated inhibition of the cytotoxic activity and cytokine production by activated natural killer cells. Cancer Res. 2006, 66, 7758-7765. [CrossRef] [PubMed]

166. Deng, Y.; Yu, J. The negative NK cell maturation checkpoint Foxo1. Oncotarget 2015, 6, 32301-32302. [CrossRef]

167. Harish, A.; Hohana, G.; Fishman, P.; Arnon, O.; Bar-Yehuda, S. A3 adenosine receptor agonist potentiates natural killer cell activity. Int. J. Oncol. 2003, 23, 1245-1249. [CrossRef] 
168. Jeffe, F.; Stegmann, K.A.; Broelsch, F.; Manns, M.P.; Cornberg, M.; Wedemeyer, H. Adenosine and IFN- $\{\alpha\}$ synergistically increase IFN-gamma production of human NK cells. J. Leukoc. Biol. 2009, 85, 452-461. [CrossRef]

169. Ohana, G.; Bar-Yehuda, S.; Arich, A.; Madi, L.; Dreznick, Z.; Rath-Wolfson, L.; Silberman, D.; Slosman, G.; Fishman, P. Inhibition of primary colon carcinoma growth and liver metastasis by the A3 adenosine receptor agonist CF101. Br. J. Cancer 2003, 89, 1552-1558. [CrossRef]

170. Antonioli, L.; Pacher, P.; Vizi, E.S.; Hasko, G. CD39 and CD73 in immunity and inflammation. Trends Mol. Med. 2013, 19, 355-367. [CrossRef]

171. Beavis, P.A.; Stagg, J.; Darcy, P.K.; Smyth, M.J. CD73: A potent suppressor of antitumor immune responses. Trends Immunol. 2012, 33, 231-237. [CrossRef] [PubMed]

172. Novitskiy, S.V.; Ryzhov, S.; Zaynagetdinov, R.; Goldstein, A.E.; Huang, Y.; Tikhomirov, O.Y.; Blackburn, M.R.; Biaggioni, I.; Carbone, D.P.; Feoktistov, I.; et al. Adenosine receptors in regulation of dendritic cell differentiation and function. Blood 2008, 112, 1822-1831. [CrossRef] [PubMed]

173. Ryzhov, S.; Novitskiy, S.V.; Goldstein, A.E.; Biktasova, A.; Blackburn, M.R.; Biaggioni, I.; Dikov, M.M.; Feoktistov, I. Adenosinergic regulation of the expansion and immunosuppressive activity of CD11b+Gr1+ cells. J. Immunol. 2011, 187, 6120-6129. [CrossRef] [PubMed]

174. Xaus, J.; Mirabet, M.; Lloberas, J.; Soler, C.; Lluis, C.; Franco, R.; Celada, A. IFN-gamma up-regulates the A2B adenosine receptor expression in macrophages: A mechanism of macrophage deactivation. J. Immunol. 1999, 162, 3607-3614. [PubMed]

175. Philip, K.; Mills, T.W.; Davies, J.; Chen, N.Y.; Karmouty-Quintana, H.; Luo, F.; Molina, J.G.; Amione-Guerra, J.; Sinha, N.; Guha, A.; et al. HIF1A up-regulates the ADORA2B receptor on alternatively activated macrophages and contributes to pulmonary fibrosis. FASEB J. 2017, 31, 4745-4758. [CrossRef] [PubMed]

176. Ryzhov, S.V.; Pickup, M.W.; Chytil, A.; Gorska, A.E.; Zhang, Q.; Owens, P.; Feoktistov, I.; Moses, H.L.; Novitskiy, S.V. Role of TGF- $\beta$ signaling in generation of CD39+CD73+ myeloid cells in tumors. J. Immunol. 2014, 193, 3155-3164. [CrossRef] [PubMed]

177. Csoka, B.; Selmeczy, Z.; Koscso, B.; Nemeth, Z.H.; Pacher, P.; Murray, P.J.; Kepka-Lenhart, D.; Morris, S.M., Jr.; Gause, W.C.; Leibovich, S.J.; et al. Adenosine promotes alternative macrophage activation via A2A and A2B receptors. FASEB J. 2012, 26, 376-386. [CrossRef]

178. Wilson, J.M.; Ross, W.G.; Agbai, O.N.; Frazier, R.; Figler, R.A.; Rieger, J.; Linden, J.; Ernst, P.B. The A2B adenosine receptor impairs the maturation and immunogenicity of dendritic cells. J. Immunol. 2009, 182, 4616-4623. [CrossRef]

179. Challier, J.; Bruniquel, D.; Sewell, A.K.; Laugel, B. Adenosine and cAMP signalling skew human dendritic cell differentiation towards a tolerogenic phenotype with defective CD8+ T-cell priming capacity. Immunology 2013, 138, 402-410. [CrossRef]

180. Ring, S.; Pushkarevskaya, A.; Schild, H.; Probst, H.C.; Jendrossek, V.; Wirsdorfer, F.; Ledent, C.; Robson, S.C.; Enk, A.H.; Mahnke, K. Regulatory T cell-derived adenosine induces dendritic cell migration through the Epac-Rap1 pathway. J. Immunol. 2015, 194, 3735-3744. [CrossRef]

181. Wilson, J.M.; Kurtz, C.C.; Black, S.G.; Ross, W.G.; Alam, M.S.; Linden, J.; Ernst, P.B. The A2B adenosine receptor promotes Th17 differentiation via stimulation of dendritic cell IL-6. J. Immunol. 2011, 186, 6746-6752. [CrossRef] [PubMed]

182. Asadzadeh, Z.; Mohammadi, H.; Safarzadeh, E.; Hemmatzadeh, M.; Mahdian-Shakib, A.; Jadidi-Niaragh, F.; Azizi, G.; Baradaran, B. The paradox of Th17 cell functions in tumor immunity. Cell. Immunol. 2017, 322, 15-25. [CrossRef] [PubMed]

183. Kreckler, L.M.; Wan, T.C.; Ge, Z.D.; Auchampach, J.A. Adenosine inhibits tumor necrosis factor- $\alpha$ release from mouse peritoneal macrophages via A2A and A2B but not the A3 adenosine receptor. J. Pharmacol. Exp. Ther. 2006, 317, 172-180. [CrossRef] [PubMed]

184. Panther, E.; Idzko, M.; Herouy, Y.; Rheinen, H.; Gebicke-Haerter, P.J.; Mrowietz, U.; Dichmann, S.; Norgauer, J. Expression and function of adenosine receptors in human dendritic cells. FASEB J. 2001, 15, 1963-1970. [CrossRef] [PubMed]

185. Panther, E.; Corinti, S.; Idzko, M.; Herouy, Y.; Napp, M.; la Sala, A.; Girolomoni, G.; Norgauer, J. Adenosine affects expression of membrane molecules, cytokine and chemokine release, and the T-cell stimulatory capacity of human dendritic cells. Blood 2003, 101, 3985-3990. [CrossRef] [PubMed] 
186. Ben Addi, A.; Lefort, A.; Hua, X.; Libert, F.; Communi, D.; Ledent, C.; Macours, P.; Tilley, S.L.; Boeynaems, J.M.; Robaye, B. Modulation of murine dendritic cell function by adenine nucleotides and adenosine: Involvement of the A(2B) receptor. Eur. J. Immunol. 2008, 38, 1610-1620. [CrossRef] [PubMed]

187. Hasko, G.; Kuhel, D.G.; Salzman, A.L.; Szabo, C. ATP suppression of interleukin-12 and tumour necrosis factor- $\alpha$ release from macrophages. Br. J. Pharmacol. 2000, 129, 909-914. [CrossRef]

188. Ryzhov, S.; Zaynagetdinov, R.; Goldstein, A.E.; Novitskiy, S.V.; Blackburn, M.R.; Biaggioni, I.; Feoktistov, I. Effect of A2B adenosine receptor gene ablation on adenosine-dependent regulation of proinflammatory cytokines. J. Pharmacol. Exp. Ther. 2008, 324, 694-700. [CrossRef]

189. Csoka, B.; Nemeth, Z.H.; Virag, L.; Gergely, P.; Leibovich, S.J.; Pacher, P.; Sun, C.X.; Blackburn, M.R.; Vizi, E.S.; Deitch, E.A.; et al. A2A adenosine receptors and C/EBP $\beta$ are crucially required for IL-10 production by macrophages exposed to Escherichia coli. Blood 2007, 110, 2685-2695. [CrossRef]

190. Cekic, C.; Day, Y.J.; Sag, D.; Linden, J. Myeloid expression of adenosine A2A receptor suppresses T and NK cell responses in the solid tumor microenvironment. Cancer Res. 2014, 74, 7250-7259. [CrossRef]

191. Cekic, C.; Sag, D.; Li, Y.; Theodorescu, D.; Strieter, R.M.; Linden, J. Adenosine A2B receptor blockade slows growth of bladder and breast tumors. J. Immunol. 2012, 188, 198-205. [CrossRef] [PubMed]

192. Bouma, M.G.; Jeunhomme, T.M.; Boyle, D.L.; Dentener, M.A.; Voitenok, N.N.; van den Wildenberg, F.A.; Buurman, W.A. Adenosine inhibits neutrophil degranulation in activated human whole blood: Involvement of adenosine A2 and A3 receptors. J. Immunol. 1997, 158, 5400-5408. [PubMed]

193. Gessi, S.; Varani, K.; Merighi, S.; Cattabriga, E.; Iannotta, V.; Leung, E.; Baraldi, P.G.; Borea, P.A. A3 adenosine receptors in human neutrophils and promyelocytic HL60 cells: A pharmacological and biochemical study. Mol. Pharmacol. 2002, 61, 415-424. [CrossRef] [PubMed]

194. van der Hoeven, D.; Wan, T.C.; Auchampach, J.A. Activation of the A3 adenosine receptor suppresses superoxide production and chemotaxis of mouse bone marrow neutrophils. Mol. Pharmacol. 2008, 74, 685-696. [CrossRef] [PubMed]

195. Chen, Y.; Corriden, R.; Inoue, Y.; Yip, L.; Hashiguchi, N.; Zinkernagel, A.; Nizet, V.; Insel, P.A.; Junger, W.G. ATP release guides neutrophil chemotaxis via P2Y2 and A3 receptors. Science 2006, 314, 1792-1795. [CrossRef] [PubMed]

196. Thiele, A.; Kronstein, R.; Wetzel, A.; Gerth, A.; Nieber, K.; Hauschildt, S. Regulation of adenosine receptor subtypes during cultivation of human monocytes: Role of receptors in preventing lipopolysaccharide-triggered respiratory burst. Infect. Immun. 2004, 72, 1349-1357. [CrossRef] [PubMed]

197. Joos, G.; Jakim, J.; Kiss, B.; Szamosi, R.; Papp, T.; Felszeghy, S.; Saghy, T.; Nagy, G.; Szondy, Z. Involvement of adenosine A3 receptors in the chemotactic navigation of macrophages towards apoptotic cells. Immunol. Lett. 2017, 183, 62-72. [CrossRef]

198. Schnurr, M.; Toy, T.; Shin, A.; Hartmann, G.; Rothenfusser, S.; Soellner, J.; Davis, I.D.; Cebon, J.; Maraskovsky, E. Role of adenosine receptors in regulating chemotaxis and cytokine production of plasmacytoid dendritic cells. Blood 2004, 103, 1391-1397. [CrossRef]

199. Gorzalczany, Y.; Akiva, E.; Klein, O.; Merimsky, O.; Sagi-Eisenberg, R. Mast cells are directly activated by contact with cancer cells by a mechanism involving autocrine formation of adenosine and autocrine/paracrine signaling of the adenosine A3 receptor. Cancer Lett. 2017, 397, 23-32. [CrossRef]

200. Gao, Z.; Li, B.S.; Day, Y.J.; Linden, J. A3 adenosine receptor activation triggers phosphorylation of protein kinase B and protects rat basophilic leukemia 2H3 mast cells from apoptosis. Mol. Pharmacol. 2001, 59, 76-82. [CrossRef]

201. Waickman, A.T.; Alme, A.; Senaldi, L.; Zarek, P.E.; Horton, M.; Powell, J.D. Enhancement of tumor immunotherapy by deletion of the A2A adenosine receptor. Cancer Immunol. Immunother. 2012, 61, 917-926. [CrossRef] [PubMed]

202. Young, A.; Ngiow, S.F.; Barkauskas, D.S.; Sult, E.; Hay, C.; Blake, S.J.; Huang, Q.; Liu, J.; Takeda, K.; Teng, M.W.L.; et al. Co-inhibition of CD73 and A2AR Adenosine Signaling Improves Anti-tumor Immune Responses. Cancer Cell 2016, 30, 391-403. [CrossRef] [PubMed]

203. Morello, S.; Capone, M.; Sorrentino, C.; Giannarelli, D.; Madonna, G.; Mallardo, D.; Grimaldi, A.M.; Pinto, A.; Ascierto, P.A. Soluble CD73 as biomarker in patients with metastatic melanoma patients treated with nivolumab. J. Transl. Med. 2017, 15, 244. [CrossRef] [PubMed]

204. Allard, B.; Pommey, S.; Smyth, M.J.; Stagg, J. Targeting CD73 enhances the antitumor activity of anti-PD-1 and anti-CTLA-4 mAbs. Clin Cancer Res. 2013, 19, 5626-5635. [CrossRef] [PubMed] 
205. Iannone, R.; Miele, L.; Maiolino, P.; Pinto, A.; Morello, S. Adenosine limits the therapeutic effectiveness of anti-CTLA4 mAb in a mouse melanoma model. Am J. Cancer Res. 2014, 4, 172-181.

206. Leone, R.D.; Sun, I.M.; Oh, M.H.; Sun, I.H.; Wen, J.; Englert, J.; Powell, J.D. Inhibition of the adenosine A2a receptor modulates expression of $\mathrm{T}$ cell coinhibitory receptors and improves effector function for enhanced checkpoint blockade and ACT in murine cancer models. Cancer Immunol. Immunother. 2018. [CrossRef] [PubMed]

207. Kjaergaard, J.; Hatfield, S.; Jones, G.; Ohta, A.; Sitkovsky, M. A2A Adenosine Receptor Gene Deletion or Synthetic A2A Antagonist Liberate Tumor-Reactive CD8+ T Cells from Tumor-Induced Immunosuppression. J. Immunol. 2018, 201, 782-791. [CrossRef]

208. Samanta, D.; Park, Y.; Ni, X.; Li, H.; Zahnow, C.A.; Gabrielson, E.; Pan, F.; Semenza, G.L. Chemotherapy induces enrichment of CD47(+)/CD73(+)/PDL1(+) immune evasive triple-negative breast cancer cells. Proc. Natl. Acad. Sci. USA 2018, 115, E1239-E1248. [CrossRef]

209. Hauser, R.A.; Olanow, C.W.; Kieburtz, K.D.; Pourcher, E.; Docu-Axelerad, A.; Lew, M.; Kozyolkin, O.; Neale, A.; Resburg, C.; Meya, U.; et al. Tozadenant (SYN115) in patients with Parkinson's disease who have motor fluctuations on levodopa: A phase 2b, double-blind, randomised trial. Lancet Neurol. 2014, 13, 767-776. [CrossRef]

210. Sako, W.; Murakami, N.; Motohama, K.; Izumi, Y.; Kaji, R. The effect of istradefylline for Parkinson's disease: A. meta-analysis. Sci. Rep. 2017, 7, 18018. [CrossRef]

211. Willingham, S.B.; Ho, P.Y.; Hotson, A.; Hill, C.; Piccione, E.C.; Hsieh, J.; Liu, L.; Buggy, J.J.; McCaffery, I.; Miller, R.A. A2AR Antagonism with CPI-444 Induces Antitumor Responses and Augments Efficacy to Anti-PD-(L)1 and Anti-CTLA-4 in Preclinical Models. Cancer Immunol. Res. 2018, 6, 1136-1149. [CrossRef] [PubMed]

212. Mediavilla-Varela, M.; Castro, J.; Chiappori, A.; Noyes, D.; Hernandez, D.C.; Stagg, J.; Antonia, S.J. A Novel Antagonist of the Immune Checkpoint Protein Adenosine A2a Receptor Restores Tumor-Infiltrating Lymphocyte Activity in the Context of the Tumor Microenvironment. Neoplasia 2017, 19, 530-536. [CrossRef] [PubMed]

213. Iannone, R.; Miele, L.; Maiolino, P.; Pinto, A.; Morello, S. Blockade of A2b adenosine receptor reduces tumor growth and immune suppression mediated by myeloid-derived suppressor cells in a mouse model of melanoma. Neoplasia 2013, 15, 1400-1409. [CrossRef] [PubMed]

214. Molck, C.; Ryall, J.; Failla, L.M.; Coates, J.L.; Pascussi, J.M.; Heath, J.K.; Stewart, G.; Hollande, F. The A2b adenosine receptor antagonist PSB-603 promotes oxidative phosphorylation and ROS production in colorectal cancer cells via adenosine receptor-independent mechanism. Cancer Lett. 2016, 383, 135-143. [CrossRef] [PubMed]

(C) 2018 by the authors. Licensee MDPI, Basel, Switzerland. This article is an open access article distributed under the terms and conditions of the Creative Commons Attribution (CC BY) license (http://creativecommons.org/licenses/by/4.0/). 